\title{
Identification of Factors Influencing Development of Photovoltaic (PV) Implementation in Singapore
}

\author{
Siu-Kit Lau ${ }^{1}$, Vesna Kosorić ${ }^{1,2,3, *}$, Monika Bieri $^{4}$ and André M. Nobre ${ }^{4}$ \\ 1 Department of Architecture, National University of Singapore, Singapore 117566, Singapore; slau@nus.edu.sg \\ 2 Balkan Energy AG, 4656 Starrkirch Wil, Switzerland \\ 3 Daniel Hammer Architekt FH AG, 4600 Olten, Switzerland \\ 4 Cleantech Energy Corporation Pte Ltd., Singapore 049482, Singapore; \\ monika.bieri@cleantechsolar.com (M.B.); andre.nobre@cleantechsolar.com (A.M.N.) \\ * Correspondence: vesna.kosoric@gmail.com; Tel.: +41-(79)-2712768
}

Citation: Lau, S.-K.; Kosorić, V.; Bieri, M.; Nobre, A.M. Identification of Factors Influencing Development of Photovoltaic (PV) Implementation in Singapore. Sustainability 2021, 13, 2630. https://doi.org/10.3390/ su13052630

Academic Editor: Domenico Mazzeo

Received: 25 January 2021

Accepted: 24 February 2021

Published: 1 March 2021

Publisher's Note: MDPI stays neutral with regard to jurisdictional claims in published maps and institutional affiliations.

Copyright: (c) 2021 by the authors. Licensee MDPI, Basel, Switzerland. This article is an open access article distributed under the terms and conditions of the Creative Commons Attribution (CC BY) license (https:// creativecommons.org/licenses/by/ $4.0 /)$.

\begin{abstract}
Despite the steady growth of grid-connected installed capacity in Singapore in the last decade and intensive government effort towards "solarization", implementation of photovoltaics (PV) and especially building-integrated photovoltaics (BIPV) into the built environment has not gathered as much momentum as would have been expected given the country's ample solar energy resource potential, strong economic fundamentals and the robust real estate sector. Based on a conducted web-survey and qualitative interviews among local professionals, this paper examines the obstacles, potentials and drivers that could facilitate and accelerate BIPV and PV façade integration, as well as needs that could encourage wider PV use. In order to define a unified strategy, aligning the stakeholders' views, the following disputable factors are pointed out and discussed: (1) incomplete understanding of BIPV and building-applied photovoltaics (BAPV) among stakeholders, (2) costs of BIPV systems, (3) low awareness of and confidence in "integrability" of PV modules, (4) incomplete knowledge about and insufficiently investigated PV performance and (5) potential of PV façade and roof integration. Since the costs are the key identified factor for BIPV implementation, life-cycle cost (LCC) assessments of PV façade and roof integrations have been performed, which supported the search for solutions to identified problems. The performed analysis and findings present the basis for the development of a long-term holistic strategy for PV implementation in Singapore that could help the highly-urbanized, tropical resource- and land-constrained island city-state reduce the dependency on fossil fuels and achieve the climate change targets, thus promoting a more sustainable built environment.
\end{abstract}

Keywords: built environment; building-integrated photovoltaics (BIPV); drivers; façade integration; holistic strategy; life-cycle cost (LCC) assessment; obstacles; photovoltaics (PV); photovoltaic (PV) integration; sustainability

\section{Introduction}

Grid-connected installed capacity in Singapore has recorded a steady growth from 10.1 MWp in 2012 to $350 \mathrm{MWp}$ in the first quarter of 2020 [1,2]. PV generation capacity accounts for only around $2 \%$ of the total installed generation capacity [1], while PV generated energy represents less than $1 \%$ of the total energy generation mix. Over $90 \%$ of PV in buildings are building-applied photovoltaics (BAPV): installations fastened with clipping elements onto roof metal sheets or assembled with metal ballasted structures onto concrete-base rooftops. The remaining PV systems are sloped-roof residential applications, scattered small ground-mounts and sporadic BIPV within which are few PV façade integrations. Floating PV systems on reservoirs have recently been launched specifically to target Singapore's space constraints [3]. For example, recently appointed by the National Water Agency, Sembcorp Industries will construct a 60 megawatt-peak (MWp), Singapore's largest floating solar PV system on Tengeh Reservoir which when completed in 2021, will 
be one of the world's largest single floating solar PV systems [4,5]. However, despite the undeniable challenges primarily related to the high-density tropical environment [6-8], PV implementation in Singapore, in particular BIPV, could be more impressive, given the ample solar energy resource potential (average solar irradiance: $1580 \mathrm{kWh} / \mathrm{m}^{2} /$ year [9]), strong real estate sector and economy fundamentals and the great effort of the government toward "solarization" [10].

With high solar irradiation, limited shading effects, ease of installation and maintenance as well as proven feasibility, rooftop BAPV systems have exceptionally high integration potential. However, dependency on fossil fuels (95\% [1]) cannot be noticeably reduced with rooftop installations alone. Compared to rooftop BAPV systems, BIPV installations (façade and other BIPV solutions) have some drawbacks such as lower solar irradiation, modest and poorly researched cost-effectiveness, unknown performance and the lack of a separate set of building standards [8], in the first place, fire safety standards. However, in order to make Singapore less dependent on fossil fuels, BIPV installations, façade and other BIPV solutions need to play a substantive role within PV integration into the built environment.

Thanks to recent developments in PV technologies enabling stimulating architectural integration [11], multi-functional BIPV solutions could provide other multiple benefits apart from electricity generation [12], by improving the quality of life, thus making the city not only more environmentally sustainable, but also more livable and enjoyable.

Owing to its global recognition as one of the world's most competitive countries and the great devotion of the government and citizens towards a sustainable future [13] on one side, and due to the space constraints (assessed possible net usable areas for PV deployment: $36.8 \mathrm{~km}^{2}$ [14]) on the other side, Singapore could contribute more to fighting climate change by setting examples of excellent practice in the city's PV transition than by the volume of $\mathrm{CO}_{2}$ reduction.

A discrepancy between the expectations and real situation regarding the progress of $\mathrm{PV}$ integration has urged researchers and other stakeholders in the PV domain to explore how to facilitate and accelerate PV integrations, especially BIPV [12-26]. Even a decade ago, in their "Achieving solar energy in architecture-IEA SHC Task 41", Wall et al. have found it surprising that solar energy systems are still not considered as mainstream technologies and are not more widely spread into the building practice [26]. Therefore, the IEA SHC Task 41 "Solar Energy and Architecture" was carried out during 2009-2012 with the aim to primarily address the issues related to architectural barriers such as: lack of awareness and knowledge among architects, lack of tools supporting the design process, and lack of products designed for building integration [26-30]. According to the study of Lu et al. [8], long-term payback period, high upfront cost and low energy conversion efficiency are the three most influential barriers to BIPV in Singapore, while on-site generation of clean energy, bundled with economic benefits, Green Mark certification (BCA Green Mark Scheme is an initiative to create a more sustainable built environment in Singapore by promoting sustainable design, construction and operating practices in buildings [31,32]) and avoidance of $\mathrm{CO}_{2}$ emissions are the most influential drivers. Apart from cost-effectiveness and other technical factors, some social and psychological factors are also deemed to play a significant role $[15,24,33,34]$. A survey on PV integration designs conducted among Singapore's professionals by Kosorić et al. [6] arrived at similar results. Several studies concluded that an interdisciplinary approach and active cooperation among stakeholders are needed to make a significant shift $[8,11,15,35]$. In order to facilitate the development of BIPV, Lu et al. suggested first a cost-benefit analysis of BIPV and effective communication channels among stakeholders, incentive policies, as well as a clear government vision followed by goals and guidelines for industry practitioners in BIPV adoption [8].

Based on a three-year comprehensive study, which included consideration of relevant environmental, economic and social sustainability factors, the research findings include: (1) identified factors affecting development of PV implementation in Singapore, given in this paper, and (2) a long-term holistic strategy for successful PV implementation into 
Singapore's built environment, consisting of: (1) multilevel mechanism framework and (2) general design framework, presented in the subsequent article.

The main goal of this paper is to provide fundamentals of a long-term holistic strategy for PV implementation in Singapore. First, based on the conducted web-survey and qualitative interviews among local professionals, this paper systematically analyzes the obstacles, potentials and drivers, needs and gaps between stakeholders with different professional backgrounds. In order to create the basis for the development of a unified strategy, it addresses the most disputable factors that have been identified. Life-cycle cost (LCC) assessments of PV integrations have been performed on local real and hypothetical buildings, to support the search for solutions to identified problems.

This study covers both BIPV and BAPV. For the avoidance of doubt, the term BIPV refers to a system which replaces a conventional building element and which is a prerequisite for the integrity of a building (e.g., if BIPV is dismounted, it has to be replaced by an adequate building component able to satisfy the same technological requirements (e.g., water-tightness, mechanical resistance, etc.)) [36,37]. Not having to satisfy the stated condition, BAPV refers to a system add-on to the building envelope using a supporting structure, which is usually used in retrofits. When it is said rooftop PV integration or PV façade integration, without specifying that it is a BIPV or BAPV system, it refers to PV integration into the roof or façade, potentially including both BIPV and BAPV systems.

The paper is divided into four sections. After the Introduction in Section 1 and the Materials and Methods in Section 2, the Results and Discussion are presented in Section 3. The obstacles, drivers and needs related to PV building integration in Singapore's websurvey are presented in Section 3.1, followed by major issues to be resolved in order to support PV building integration in Singapore in Section 3.2. Conclusions are presented in Section 4. Some survey and LCC results are given in the Appendix A.

\section{Materials and Methods}

Figure 1 provides a schematic representation of the overall research methodology in the form of an activity flow consisting of seven main phases.

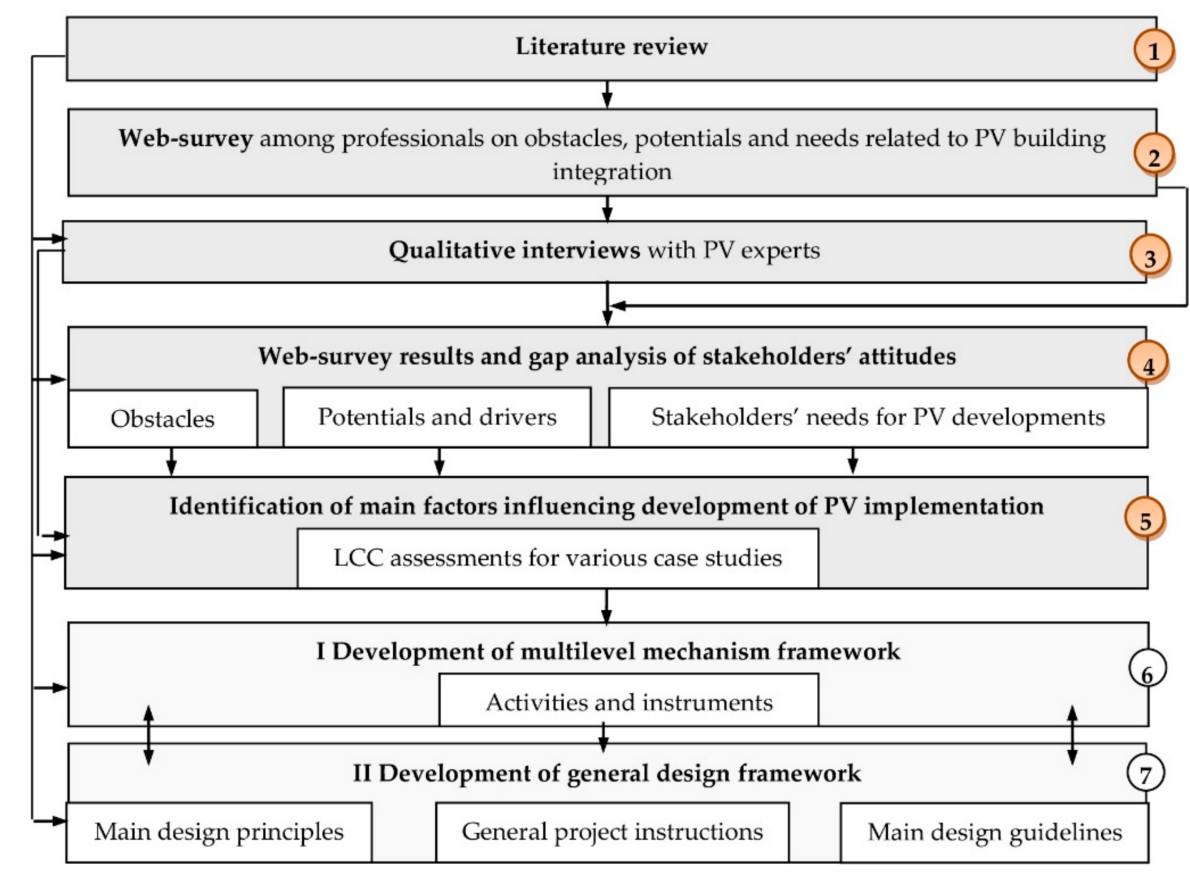

Figure 1. A methodology related to the development of a long-term holistic strategy for successful PV (photovoltaics) implementation into Singapore's built environment (the phases 1-5 (in orange) are performed in the first part of the study related to this paper). 
After the web-survey (explained in Section 2.1), we carried out qualitative interviews (phase 3 in Figure 1) with ten professionals who have extensive experience in PV and BIPV in Singapore. These interviews went into greater depth and detail and explored the unique experiences and opinions of interviewees on the relevant problems. They were of special help in interpreting web-survey results (phase 4 in Figure 1) which revealed a significant gap between PV experts, architects and other professionals in Singapore, as well as between professionals with and without experience in PV building integration, in perceiving the hindering factors and those that could facilitate BIPV implementation in Singapore. Based on web-survey results and gap analysis, this study identifies and clarifies the most disputable issues (phase 5 in Figure 1) related to widespread PV implementation. LCC assessments (explained in Section 2.2) of PV building integrations on local real and hypothetical buildings have been performed, which support the resolution of identified problems.

Based on a systematic analysis of identified disputable issues and literature review, the holistic strategy consisting of: (1) multilevel mechanism framework (phase 6 in Figure 1) and (2) general design framework (phase 7 in Figure 1) was defined and is the subject of subsequent publication.

\subsection{Web-Survey}

Drawing upon the literature review (phase 1 in Figure 1), a web-survey with local professionals (phase 2 in Figure 1) was employed as a research instrument to identify obstacles, potentials and drivers, as well as stakeholders' needs related to PV building integration in Singapore. It was carried out in May 2018. An anonymous, multiple-choice questionnaire was created using the online (Google Forms) platform and the questionnaire took approximately $15 \mathrm{~min}$ to complete. The introductory section consisted of 5 questions about the respondents' professional background, while the main part of the questionnaire had 15 questions divided into three sub-groups aiming to identify: (1) obstacles, (2) potentials and drivers and (3) needs related to PV building integration in Singapore that could encourage wider PV use. Mandatory questions were followed by an optional field, inviting professionals to issue comments.

Invitations to participate in the survey were sent to 1200 professionals who are based and working in Singapore, and a total of 101 valid completed responses were obtained. As shown in Table 1, the highest response rate was from architects $(78.2 \%)$ and professionals with over 15 years of experience accounted for little more than a half of the sample (50.5\%). Around one-half of all the respondents (49.5\%) and a third (33.3\%) of involved architects have experience in PV building integration (BIPV and BAPV), but only $23.8 \%$ of the respondents and $8.9 \%$ of architects have experience with façade BIPV.

\subsection{LCC Assessment Method}

Assuming that economic performance of PV integration could vary significantly not only between the roof and façade, but also depending on the type of PV integration (existing/new building; BIPV/BAPV), in this paper, the LCC analysis was performed for three case studies:

1. BAPV façade system as an additional cladding on the existing building-Case study 1 ,

2. BIPV façade system as a cladding on a new hypothetical building-Case study 2 and

3. BIPV as a roof canopy-Case study 3.

One of the key inputs into the analysis is naturally the underlying electricity price which provides us with a tangible benefit. We defined for this input three wholesale power price scenarios based on the methodology developed by the Solar Energy Research Institute of Singapore (SERIS) [38]. These price forecasts have been updated with the latest information on Singapore's reserve margin and applying the 18 September 2020 oil price futures curve as a reference for the underlying fuel cost (spot price 43.2 US Dollars/barrel which forms the underlying basis for Singapore's gas import cost). As the Singapore electricity market is liberalized and divides consumers into contestable and non-contestable 
categories by threshold of usage intensity [39-41], based on the wholesale power price scenarios (i.e., Uniform Singapore Energy Price (USEP)), two different customer profiles have been chosen: (a) a contestable client, who is assumed to buy power at the cost of USEP plus $0.01 \mathrm{SGD} / \mathrm{kWh}$ for the grid fee and (b) a non-contestable client, who pays the Singapore Power regulated tariff. The different scenarios including USEP scenarios, contestable price scenarios and non-contestable price scenarios are shown in Figures 2-4 respectively.

Table 1. Demographic profiles of survey respondents (BIPV (building-integrated photovoltaics); BAPV (building-applied photovoltaics)).

\begin{tabular}{|c|c|c|c|c|c|}
\hline & Frequency & Pct. (\%) & & Frequency & Pct. (\%) \\
\hline \multicolumn{3}{|c|}{ Profession } & \multicolumn{3}{|c|}{ Industry sector } \\
\hline Architect & 79 & 78.2 & Design & 45 & 44.6 \\
\hline Consultant & 3 & 3.0 & Construction & 12 & 11.9 \\
\hline PV expert & 7 & 6.9 & Planning & 2 & 2.0 \\
\hline Manager & 2 & 2.0 & Engineering & 2 & 2.0 \\
\hline Engineer & 4 & 4.0 & Academic Research & 6 & 5.9 \\
\hline Designer & 1 & 1.0 & Consulting & 18 & 17.8 \\
\hline \multirow[t]{2}{*}{ Other } & 5 & 5.0 & Project management & 13 & 12.9 \\
\hline & & & Other & 3 & 3.0 \\
\hline \multicolumn{3}{|c|}{ Years of professional experience } & \multicolumn{3}{|c|}{ Experience in PV building integration (BIPV + BAPV) } \\
\hline $1-5$ & 12 & 11.9 & Yes & 50 & 49.5 \\
\hline $5-10$ & 13 & 12.9 & No & 51 & 50.5 \\
\hline $11-15$ & 25 & 24.8 & \multicolumn{3}{|c|}{ Experience in PV façade integration } \\
\hline $15-20$ & 8 & 7.9 & Yes & 24 & 23.8 \\
\hline$>20$ & 43 & 42.6 & No & 77 & 76.2 \\
\hline
\end{tabular}

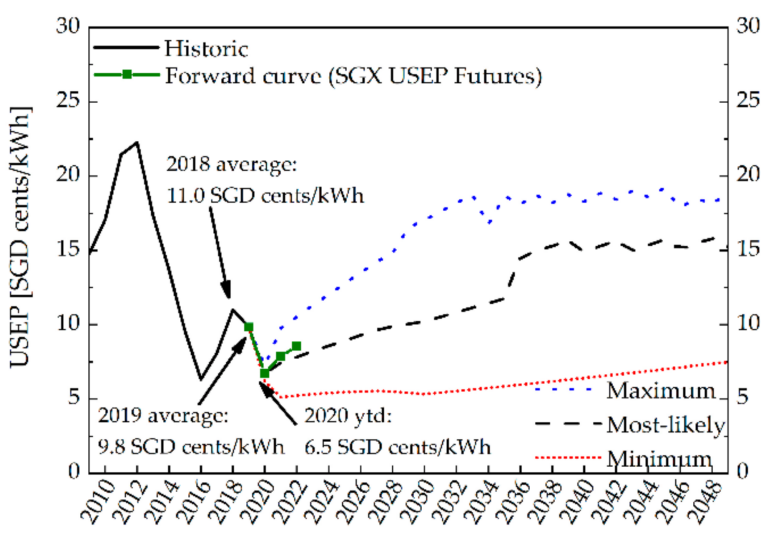

Figure 2. Uniform Singapore Energy Price (USEP) scenarios. Source: Monika Bieri, Cleantech Solar, using methodology developed by SERIS (Solar Energy Research Institute of Singapore) [38] using the latest oil price forward curve (i.e., 18 September 2020) and the latest information on reserve margin.

Furthermore, three PV module types are used, two for the façade application, including: (a) Colored cladding panels from Kromatix with an area factor of $170 \mathrm{Wp} / \mathrm{m}^{2}$, (b) AGC BIPV modules with an area factor of $156 \mathrm{Wp} / \mathrm{m}^{2}$ and (c) $380 \mathrm{Wp}$ PERC (Passivated Emitter Rear Cell) Double-Glass modules, for the roof canopy. 


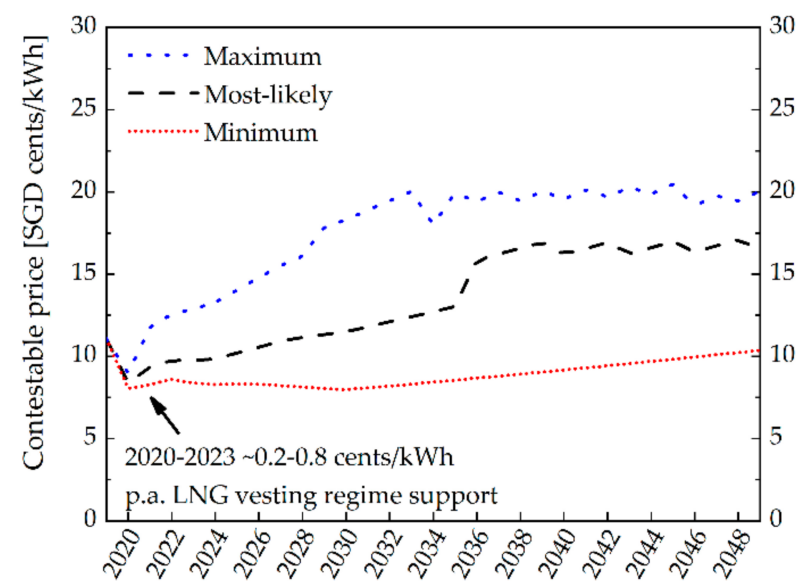

Figure 3. Contestable price scenarios (the most-likely price scenario has been used for the analysis). Source: Monika Bieri, Cleantech Solar, assuming a contestable client pays $0.01 \mathrm{SGD} / \mathrm{kWh}$ grid fees (varies among liberalized clients) and other fees, and assuming that contestable clients will need to contribute to the liquefied natural gas (LNG) vesting regime until it ends in June 2023. the most-likely price scenario

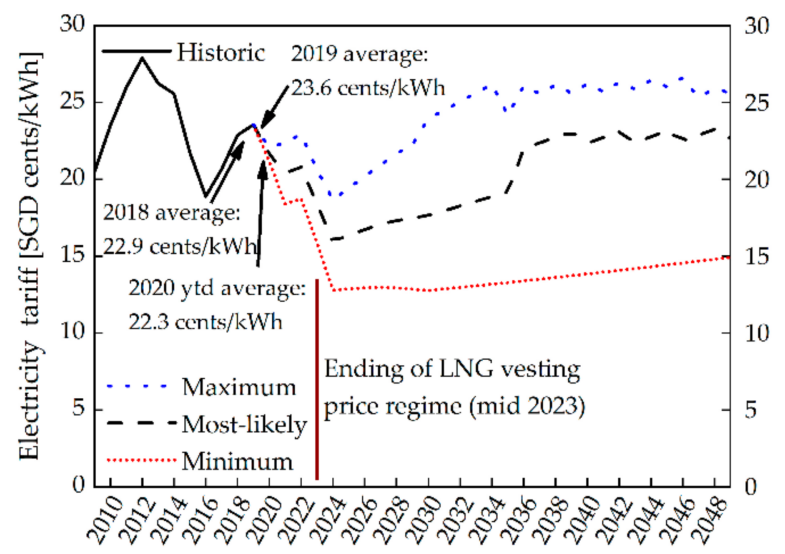

Figure 4. Non-contestable price scenarios (the most-likely price scenario has been used for the analysis). Source: Monika Bieri, Cleantech Solar, assuming a non-contestable client, whereas Singapore power procures power at USEP after the liquefied natural gas (LNG) vesting price regime ends.

Besides the generation of green electricity, solar applications attached directly to the building surface can have a positive effect on energy savings thanks to the cooling effect and less air conditioning usage [42]. For our case study presented in Section 3.2.5, the household consumption of the analyzed building in 2015 is $531.7 \mathrm{MWh}$. Based on the energy consumption pattern of different household units in Singapore given in the study of Xu and Ang [43], and the structure of household units of the studied block (120 units of 3-room flats, 22 units of 4-room flats, 2 units of 5-room flats and 4 units of executive flats), it can be assumed that $209 \mathrm{MWh}$ is consumed for air conditioning. Assuming that cooling is on average performed for reducing the room temperature by $6{ }^{\circ} \mathrm{C}$ compared to the outside temperature, cooling consumption of the building is roughly $34.8 \mathrm{MWh} / 1^{\circ} \mathrm{C}$ of the temperature difference. Based on the discussions with PV experts, we include the impact of potential energy saving effect of PV façade in the economic analysis. Accordingly, we are analyzing and showing the economic outcome for the façade case studies (case studies 1 and 2) for the selected building with annual houshold electricity consumption of 531.7 MWh, with three different outcomes, i.e., energy saving scenarios:

(a) no energy savings included (assumption that PV façade has no effect on reduction of effective outside temperature relevant for cooling, i.e., air-conditioning), 
(b) $\sim 34.8 \mathrm{MWh}$ annual savings thanks to a $1{ }^{\circ} \mathrm{C}$ reduction of the indoor/outdoor temperature (assumption that PV façade reduces effective outside temperature relevant for cooling for $1{ }^{\circ} \mathrm{C}$, i.e., air conditioning) and

(c) $\quad 69.7 \mathrm{MWh}$ annual savings thanks to a $2{ }^{\circ} \mathrm{C}$ reduction of the indoor/outdoor temperature (assumption that $\mathrm{PV}$ façade reduces effective outside temperature relevant for cooling for $2{ }^{\circ} \mathrm{C}$, i.e., air conditioning).

The influence of the three energy saving scenarios on the LCC results for the two façade case studies can be seen in Tables A1-A6 in Appendix A.

The discount rate is based on the weighted-average cost of capital calculation and varies between BIPV and BAPV applications. While both use an equity cost assumption of $8.2 \%$ (based on the 30 -year Singapore government yield $(1.26 \%$, [44]) as a risk-free rate proxy, a market risk premium of $6.70 \%$ (used by Energy Market Authority (EMA) to calculate the vesting price for gas-fired power stations [45]) and a beta of 1), the debt cost differs due to the different nature of the investment. For BIPV, where the façade will be an integral part of the building, the 15-year housing lending rate $(2.84 \%$ [46]) has been used (i.e., the façade cost will be financed as a part of the entire real estate investment), while for BAPV, a debt premium of $3.5 \%$ has been added to the 15 -year government yield of $1.32 \%$ [ 47$]$, resulting in $4.8 \%$. Applying a $70 \%$ vs. $30 \%$ debt to equity split and using the $17 \%$ corporate tax rate, the resulting discount rates are $4.0 \%$ for BIPV and $5.2 \%$ for BAPV. Regarding the replacement material, a cost of SGD $350 / \mathrm{m}^{2}$ has been used as an assumption for an "avoided" façade cladding cost (either for new buildings, or avoided refurbishment for existing buildings).

In Section 3.2.5, in figures presenting the LCC results for the three cases, we are showing economic results for one variation of the scenarios per case study, called the "base-case". They are based on two different methods:

1. One showing the discounted life-cycle cost in SGD per square meter "LCC $/ \mathrm{m}^{2}$ ", as defined in [48], which can be compared to the traditional cost of façades and

2. The typical financial metrics (i.e., Net Present Value (NPV) in SGD, Internal Rate of Return (IRR) \% and discounted payback period (DPB, years)) for a 30-year building life.

The rest of the performed calculations and the detailed cost assumptions based on industry experts' inputs are shown in Tables Tables A1-A7 in the Appendix A.

\section{Results and Discussion}

The following section shows the results of the research, divided into two main parts: 3.1. Obstacles, drivers and needs related to PV building integration in Singapore-websurvey and 3.2. Major issues to be resolved in order to support PV building integration in Singapore.

\subsection{Obstacles, Drivers and Needs Related to PV Building Integration in Singapore-Web-Survey}

The survey results are discussed in the subsequent three sections. Individual responses are systematically analyzed considering stakeholders' professional and PV expertise background, based on which the relevant identified gaps, i.e., overlaps are discussed.

\subsubsection{Obstacles to Widespread Implementation of BIPV in Singapore}

Apart from insufficient solar exposure in a high-density environment, the web-survey in Singapore confirms that high costs are the most critical general obstacle to widespread implementation of BIPV (see Figure 5), as hypothesized by the authors and identified in the studies at the international [20,21,49] and local level [8]. However, further analysis shows that respondents' professional background significantly shapes their attitudes toward the cost parameter. As shown in Figure 1 in Appendix A, as much as $43 \%$ of PV experts did not include costs among the top three obstacles to widespread implementation of BIPV in Singapore, whereas only $20 \%$ of architects and $20 \%$ of other professions had done the same. The second most important among the seven ranked general obstacles is the limited variety of PV modules suitable for BIPV integration (size, color, etc.) and insufficient education 
of professionals in BIPV and PV façade integration. Professionals with experience in PV building integration deem that a certain degree of resistance from stakeholders towards BIPV is the second most critical obstacle that needs to be overcome, right after the cost issue.

Lack of information about advantages/disadvantages of BIPV

Lack of education in BIPV and PV façade integration

Certain degree of resistance towards BIPV and PV façade integration

Lack of practical guidelines and handbooks on BIPV implementation

BIPV is not an obligatory/integral part of the design process

Limited variety of PV modules at the market

Too high costs of BIPV and PV façade integrations
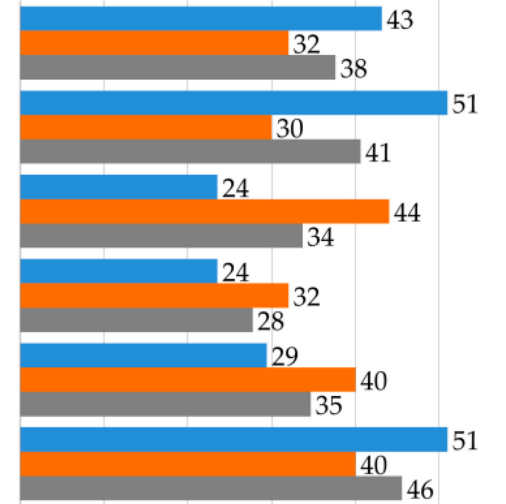

1

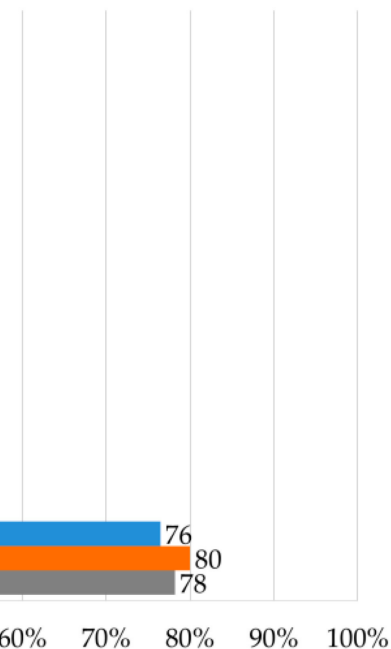

$\begin{array}{lllllllllll}0 \% & 10 \% & 20 \% & 30 \% & 40 \% & 50 \% & 60 \% & 70 \% & 80 \% & 90 \% & 100 \%\end{array}$

nespondents without experience in PV building integration $\quad$ Respondents with experience in PV building integration $\quad$ All respondents

Figure 5. Respondents' attitudes towards general obstacles to the implementation of BIPV in Singapore.

Among separately investigated technological obstacles, the low cost-effectiveness of $\mathrm{BIPV}$ technology is the most prominent, followed by sensitivity to shading and maintenance issues (see Figure 6). Responses to this question also reflect different understandings of BIPV technology among professionals with different backgrounds. As shown in Figure A2 in Appendix A, 71\% of PV experts have selected PV modules' sensitivity to shading effects among the top two technological obstacles, while only $39 \%$ of architects did the same. The results show that respondents with experience in PV building integration put much more attention to the shading sensitivity compared to professionals without such experience who at the same time attach greater weight to durability and maintenance of BIPV compared to professionals with experience in PV building integration.

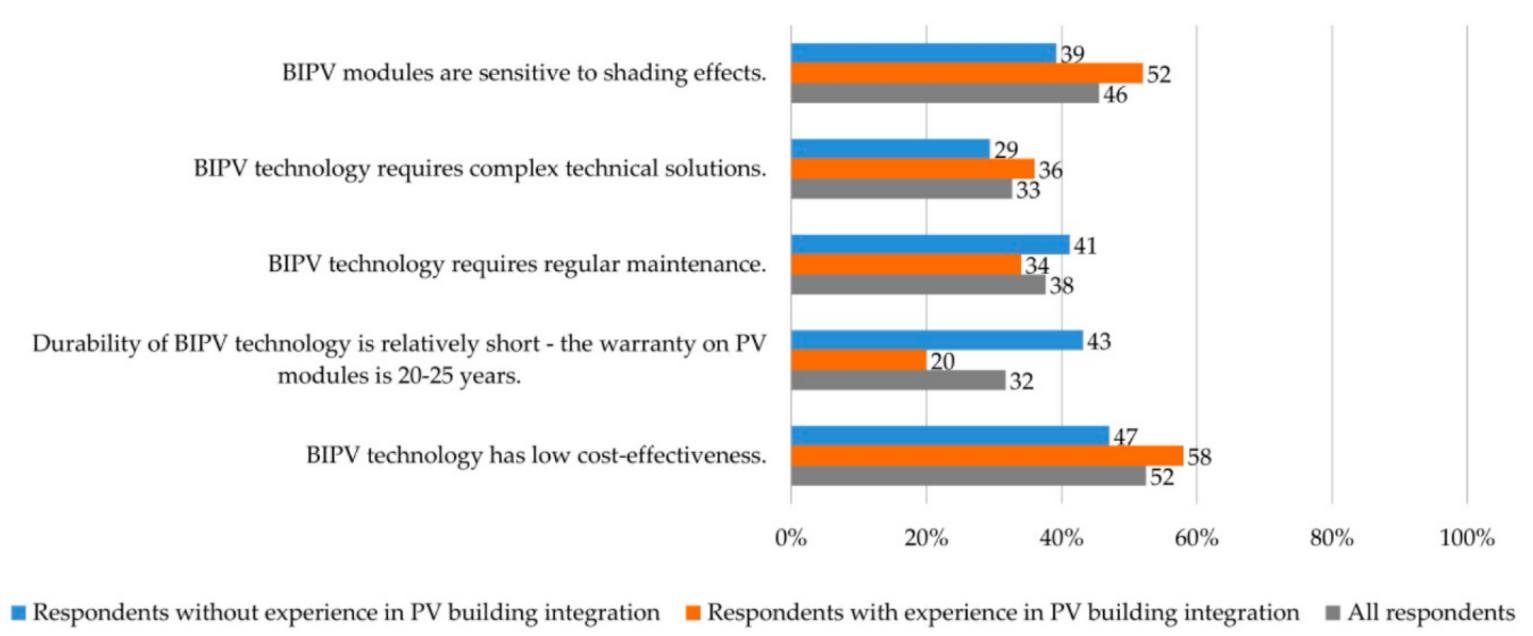

Figure 6. Respondents' attitudes toward technological obstacles to the implementation of BIPV in Singapore.

The great discrepancy in answers between the respondents with and without experience in PV building integration concerned the obstacles related to the availability of $P V$ products. The professionals without experience in PV building integration attribute dark colors of PV modules as an obstacle to BIPV development much more than the experienced 
group, which tends to attach higher importance to availability, delivery time and costs of custom-made PV products (see Figure 7).

Availability of PV modules' producers and suppliers is insufficient.

Availability and costs of mounting systems for PV modules are unfavorable.

Availability, delivery time and costs of custom-made PV modules are unfavorable.

The colour of widely available PV modules on the market is mostly dark.
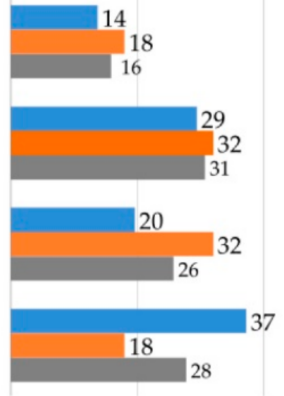

$0 \% \quad 20 \% \quad 40 \%$

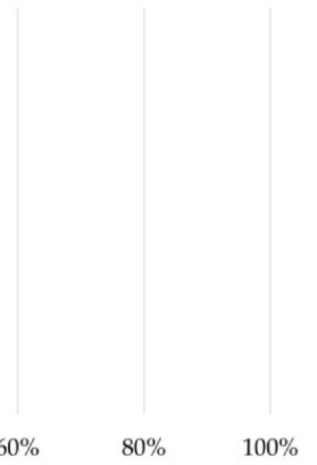

$00 \%$

= Respondents without experience in PV building integration $=$ Respondents with experience in PV building integration $\quad$ all respondents

Figure 7. Respondents' attitudes toward obstacles to BIPV in Singapore related to PV products' availability.

Regarding obstacles related to the design process, all stakeholders share similar views regarding the three options offered. The lack of tools and software that support the BIPV design process in the early design stages (39\%), as well as too late consideration of BIPV in the design process (44\%), are seen as significantly more important obstacles than the fact that producers/suppliers are consulted too late in the design process (18\%).

Besides high initial costs and lower electricity production compared to rooftop installation, glare and reflectance from PV as well as the risk of mishandling PV modules if installed within the reach of tenants are highly positioned on the list of concerns related to future PV façade integration into Housing E Development Board (HDB) buildings (public housing estates in which $85 \%$ of Singapore's population live [50]), see Figure 8).

Glare and reflectance from PVs can affect residential neighborhoods.
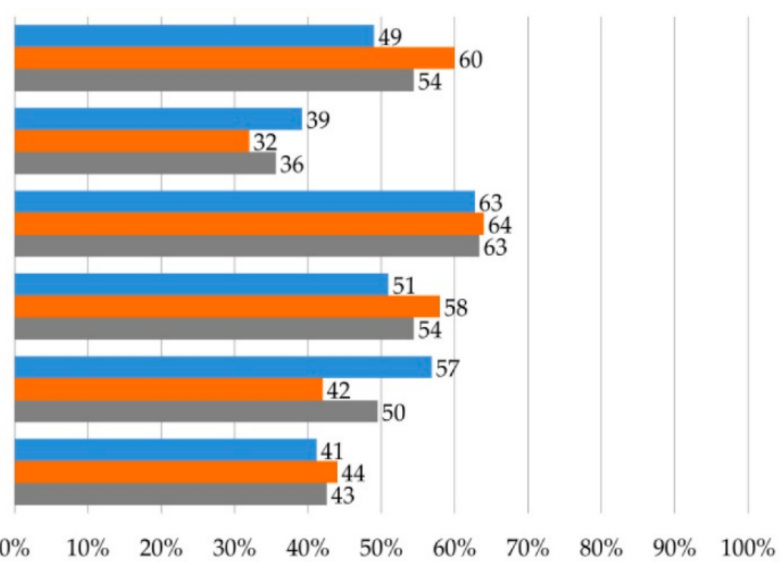

— Respondents without experience in PV building integration = Respondents with experience in PV building integration all respondents

Figure 8. Respondents' attitudes towards obstacles to future PV façade integration into HDB (Housing \& Development Board) buildings.

\subsubsection{Potentials and Drivers to Facilitate Implementation of BIPV in Singapore}

The improvement of techno-economic performance and enhancement of PV products' "integrability", i.e., ability for high-quality building envelope integration including customization, standardization and modularity, share the first place as the most important drivers that could facilitate BIPV implementation and PV façade integration (see Figure 9). This coincides with the results of the survey conducted by Lu et al., where few choices for BIPV products were ranked as the sixth among 18 barriers to BIPV in Singapore [8]. As shown in Figure 9, the successful inspiring BIPV projects built in Singapore and increas- 
ing collaboration between stakeholders are the second and third most important factors. The further analysis indicates a gap in opinions between PV experts, architects and other professionals with regard to the drivers. Possible solutions for bridging the identified gap could be: (a) considering BIPV technology in the early design stage, (b) increasing expertise of architects in PV building integration and (c) developing a handbook with guidelines on all steps in the PV building integration (including the actual and hypothetical examples of PV roof and façade integrations in Singapore).

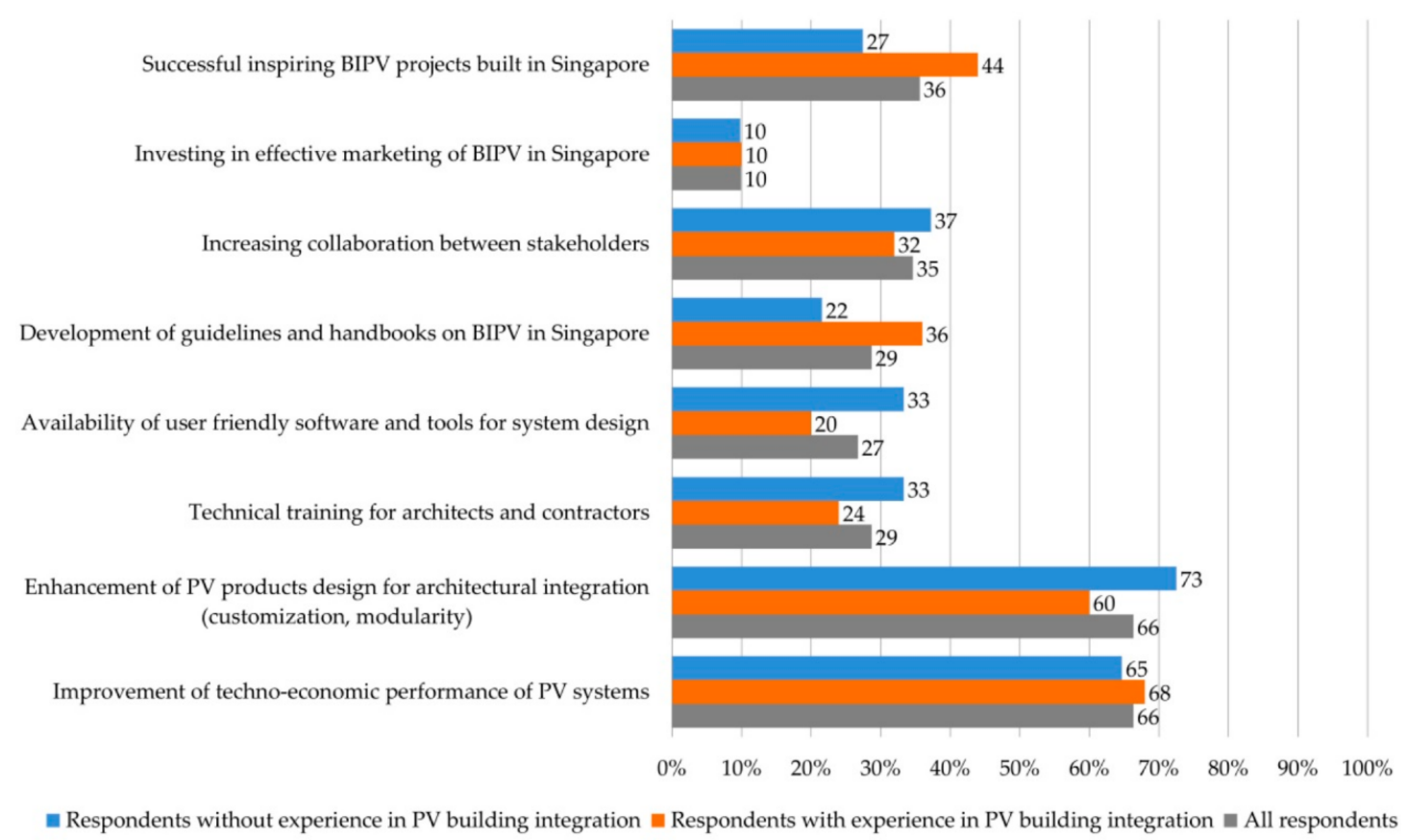

Figure 9. Respondents' attitudes toward drivers facilitating BIPV implementation in Singapore.

When asked to rank the following three items: inspiring BIPV projects, lower PV system prices and new PV modules in different colors, the respondents ranked the costs as the first (55\%), the inspiring BIPV projects as the second (26\%) and new PV modules in different colors as the third (19\%) critical item that could boost PV building integration in Singapore. The importance of inspiring BIPV projects, designed by famous architects and built in Singapore declines with the decreasing of respondents' PV expertise (respondents with experience in PV building integration: 32\%; respondents without experience in PV building integration: $20 \%$ ), suggesting that the more experienced the respondent, the more value they attach to the exemplary role of high-quality BIPV projects, as well as to the guidelines as a means of achieving high-quality designs (see Figure 6). A further analysis leads to a somewhat unexpected outcome: architects do not consider extraordinary BIPV projects as the most important for BIPV development as, for example, PV experts do. They give much higher importance to costs and consider the inspiring projects similarly important as the development of new PV modules in different colors.

The results of the survey revealed that $66 \%$ of respondents believe that high-quality designs can only be achieved by the development of new PV modules of different color and texture, since PV products do not offer enough opportunities for quality designs. The same percentage of survey participants believes that enhanced "integrability" of PV products would be an important driver for BIPV development (see Figure 6). Further analysis shows that the respondents with experience in PV façade integration are more satisfied with the capabilities of the existing PV products compared to those without façade experience. The respondents without façade experience rather believe that new PV modules are needed for achieving quality BIPV projects. 
When asked to choose three items which could accelerate PV façade integration in Singapore, the respondents opted for the new generation PV whose cost would be similar to the façade cladding as the first-ranked item, new technology enabling reduced shading losses and allowing greater design flexibility as the second and a larger variety of aesthetically pleasing PV modules of different colors and textures on the market as the third most critical item (see Figure 10).

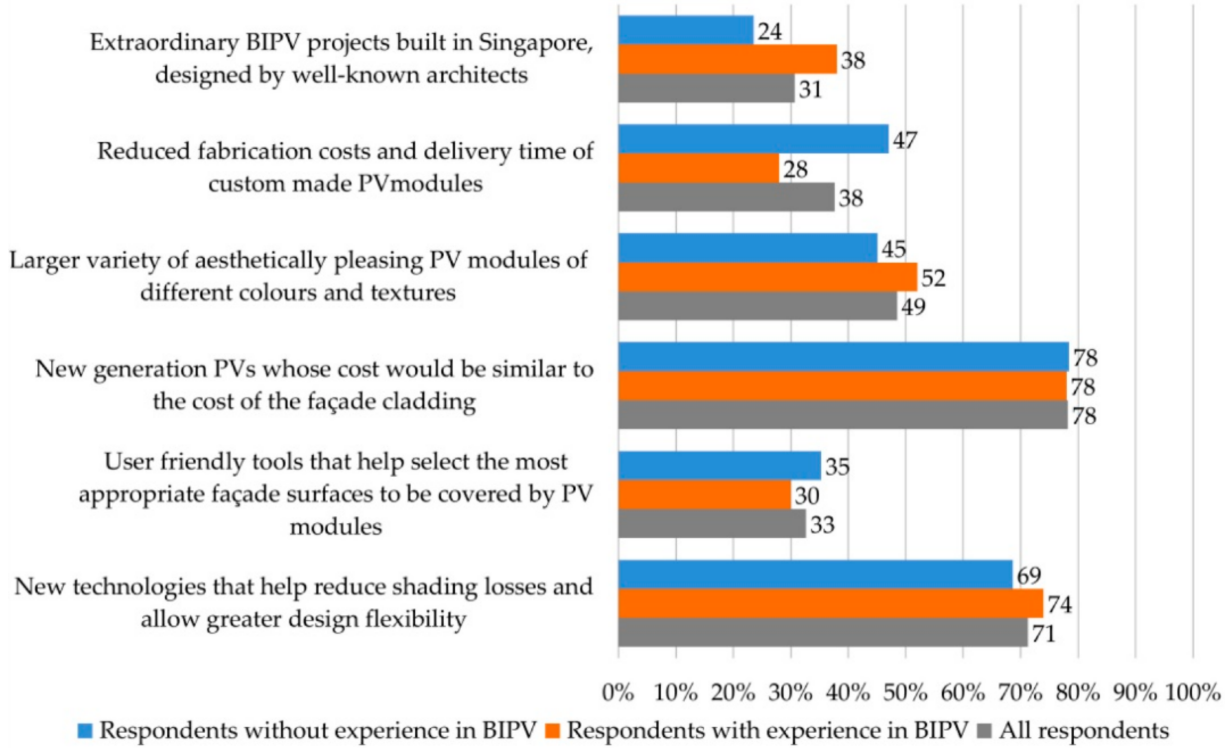

Figure 10. Respondents' attitudes towards 3 items which could accelerate PV façade integration in Singapore.

3.1.3. Needs Related to PV Building Integration in Singapore That Could Encourage Wider PV Use

In choosing between creativity and technical expertise, in the respondents' view, creativity is almost four times less important for designing BIPV projects than the technical expertise of architects in the area of PV building integration. Bearing in mind that the majority of respondents are architects, this is a somewhat surprising result of the survey.

Asked about the importance (not important, slightly important, moderately important, important and very important) of the handbook with guidelines about all steps in PV building integration design process, including actual and hypothetical examples of PV roof and façade integrations, around three-quarters (74\%) of all respondents have rated such handbook as very important and important.

Both architects and PV experts have an aligned and positive view of rooftop PV integrations, including both BIPV and BAPV implementations. When asked to rate the importance (not important, slightly important, moderately important, important and very important) of $P V$ rooftop gardens, $75 \%$ of survey participants saw them as important or very important. When asked to choose between rooftop and façade integration for demonstrating green, ecological and future-oriented image in public, 67\% of survey participants would choose rooftop integrations.

When asked to choose two items which, in their opinion, represent the most important benefits related to potential future PV façade integration into HDB buildings (see Figure 11), respondents opted for energy and socio-psychological issues.

The production of electricity that fully powers common services in the daytime was ranked as the most important, followed by motivating and empowering of residents and visitors towards sustainable behavior. Actually, the motivating and empowering of residents is the first ranked benefit by respondents with experience in BIPV. These results confirm the high importance of social and psychological aspects, apart from unequivocally important energy and economic aspects in the domain of PV façade integration. 


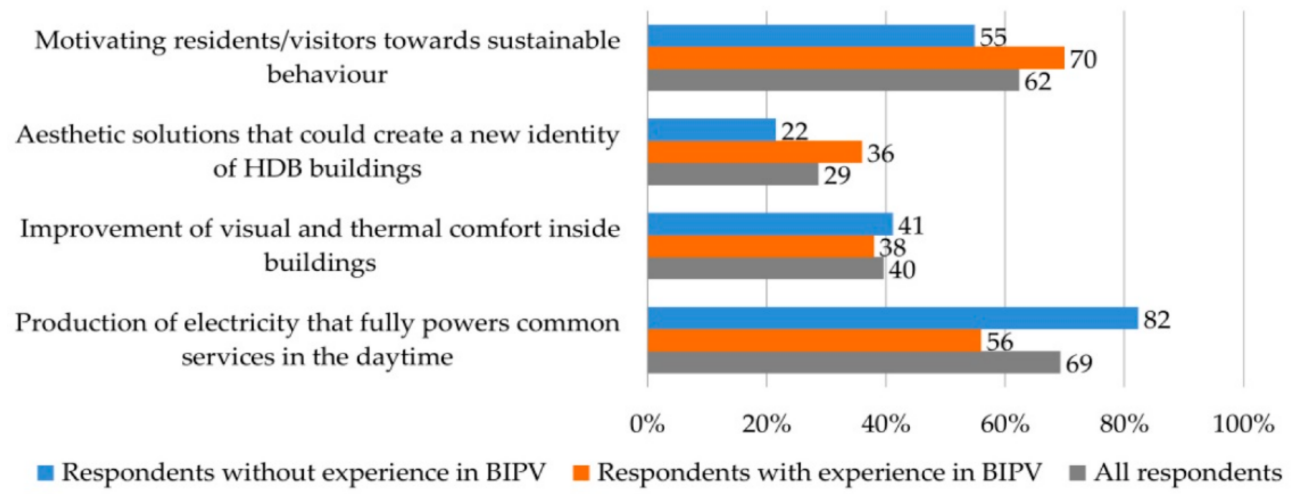

Figure 11. Respondents' attitudes towards benefits of PV façade integration into HDB buildings.

\subsection{Major Issues to Be Resolved in Order to Support PV Building Integration in Singapore}

Different respondent groups differentiated by the degree of PV building integration expertise perceive differently obstacles to widespread BIPV implementation, potentials and drivers for boosting BIPV integration as well as various needs in the context of supporting wider PV use in Singapore. Since the number of professionals without PV façade integration experience is significantly larger-almost three quarters, this may result in an environment that is not conducive to further PV façade integration development. Recently, Chang et al. [51] have emphasized the importance of forming a shared vision of BIPV among relevant stakeholders for the development of comprehensive strategic plan of BIPV. Since Singapore is also a relatively small city-state to host several different PV growth strategies, a unified and focused strategy which will help align the views of relevant professionals is a necessary precondition for sustainable growth of BIPV and other PV integration projects in Singapore.

Based on the web-survey and face-to-face discussions with PV experts, the following disputable issues have been pointed out and discussed in the Sections 3.2.1-3.2.5:

1. Incomplete understanding of BIPV and BAPV among stakeholders,

2. Costs of BIPV systems,

3. Low awareness of and confidence in "integrability" of PV modules,

4. Incomplete knowledge about and insufficiently investigated PV performance and

5. Potential of PV façade and roof integration.

The research offers potential concrete solutions for the identified issues in the form of two frameworks given in the subsequent publication.

\subsubsection{Incomplete Understanding of BIPV and BAPV among Stakeholders}

BIPV and BAPV are not always seen as two different integration solutions among different stakeholders. Considering that the two systems differ significantly in terms of the functional and constructive role they play in a building, and usually also in aesthetics and economic viability, the lack of complete distinction and understanding of BIPV and BAPV may lead to inadequate decision-making in the PV integration design. Design teams should be aware that the design of BIPV is about finding a balance between functional-formal and techno-economic performance, where all the relevant criteria are usually considered as equally important, whereas in the case of BAPV systems, techno-economic criteria are usually dominant. In that context, it makes a great difference whether PV are intended for new or existing buildings, which requires knowledge about PV modules' "integrability", customization and modularity in order to make proper decisions in the design process.

\subsubsection{Costs of BIPV Systems}

Based on the conducted web-survey and intensive face-to-face discussions with PV experts it can be concluded that the role of building-integrated PV modules in the replacement of conventional building envelope materials may be neglected among different 
stakeholders. Despite the fact that PV are constantly approaching conventional building envelope materials in their characteristics due to the technological development and the fall in prices of PV modules, they are still perceived as unsightly elements of dark color and limited standard dimensions, which create additional cost. It is often forgotten how expensive conventional façades are, while PV are treated mostly as an additional expense [52]. For example, in their recent study in which they evaluated the economic feasibility of a BIPV system, Gholami and Røstvik concluded that the perception of BIPV technology as an unfeasible system on the building skins should change [53]. According to the authors, BIPV materials should be seen as a reasonable option for the building envelope no matter what direction or orientation, with at least one privilege compared to other alternatives, which is the dual functionality of the system that makes the envelope a source of income for the building. Section 3.2.5 presents the conducted LCC assessments for PV façade and roof integrations in Singapore, which supported the development of the strategy.

\subsubsection{Low Awareness of and Confidence in "integrability" of PV Modules}

The analysis of the web-survey results and discussions with PV experts indicate that there is a certain degree of resistance from professionals and investors towards BIPV and PV façade integration in Singapore (see Figure 2), most likely caused also by the identified low level of knowledge and awareness about the "integrability" of PV modules. Considering that architects' perceptions of PV and BIPV, often influenced by aesthetically unappealing $\mathrm{PV}$ installations and sometimes shared by the construction sector, can slow down BIPV uptake despite potential investor enthusiasm, Ballif et al. indicate that from the very first design stage, a better awareness of the possibilities offered by PV modules needs to be shared among the stakeholders involved [11]. Intended to provide recommendations and arguments to assist design professionals in the communication of solar energy strategies, the Task 41 participants have developed a communication guideline. Including convincing arguments and facts, the guideline is developed as a tool to support architects in the communication process with clients, authorities and contractors [30].

\subsubsection{Incomplete Knowledge about and Insufficiently Investigated PV Performance}

In addition to the aesthetic issues related to PV integration, there are also technical problems, among which is the PV performance. On the one hand, the incomplete knowledge and low awareness about the performance of PV, and on the other, still insufficiently investigated PV performance, especially in the domain of BIPV, PV façade integrations and generally, the impact of integrated PV on energy consumption and comfort within buildings, stand in the way of rapid deployment of PV systems within Singapore's built environment. This implies that data related to the performance of PV are not only under-researched, but also inadequately or insufficiently carefully documented and poorly represented within the building sector.

\subsubsection{Potential of PV Façade and Roof Integration \\ Potential of PV Façade Integration}

Both negative and positive effects play an important role in assessing the potential of PV façade integrations. The negative facts include lower solar irradiation on vertical façade surfaces compared to rooftops in the tropics, (cca. $-48.5 \%$ (east) up to $-64.3 \%$ (south) vs. horizontal surfaces [54]), shading effects from the surrounding, commonly required customization, more demanding installation and maintenance of PV modules. On the other hand, the benefits certainly imply much greater surface comparing to rooftops [3], visual dominance as well as the potential for contributing to thermal and visual comfort in buildings. In addition to all of that, finally, the assessment of the potential of $\mathrm{PV}$ façade integrations in Singapore is inevitably influenced by the consideration of the economic aspect.

The estimation of costs for PV façade integration is generally not easy. In addition to the specificity of façade integration, this is largely due to the lack of local references 
and the lack of experience in façade integration. The PV façade integration costs are greatly influenced by: (a) type of PV integration (existing/new building; BIPV/BAPV), (b) types of PV modules, (c) area of PV modules, (d) customization, (e) utilization of module level power electronics (MLPE), usually used in the case of partial shading, instead of conventional string inverter systems, (f) type of mounting system and technique and (7) maintenance costs.

LCC assessment for BAPV façade system as an additional cladding on the existing building-Case study 1.

The existing 12-storey residential building, built along an east-west orientation (Figure 12a,b [6]), with 120 apartments and the annual electricity consumption of 598.9 MWh (of which $\sim 89 \%$ from household consumption, $\sim 11 \%$ from public consumption) is used as a case study. The LCC assessment is performed for the two following designs:

(a) east-north design, with PV modules as additional cladding on the eastern end-wall $\left(170.1 \mathrm{~m}^{2}\right)$ and northern corridors, i.e., common access balconies $\left(470 \mathrm{~m}^{2}\right)$, (total PV modules area: $640.1 \mathrm{~m}^{2}$ ) (Figure 12c,d) and

(b) east-west design, with PV modules on the eastern end-wall $\left(170 \mathrm{~m}^{2}\right)$ and west endwall $\left(170 \mathrm{~m}^{2}\right)$, (total PV modules area: $340 \mathrm{~m}^{2}$ ).

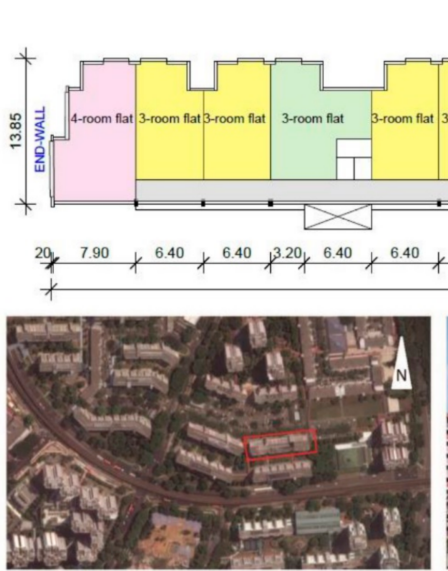

(b)

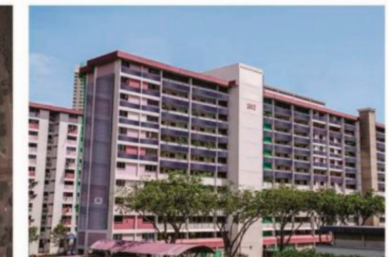

(c)

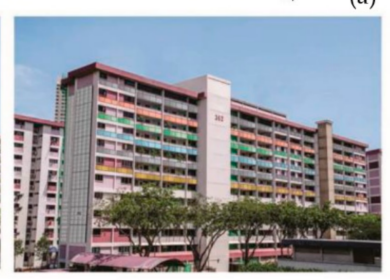

(d)

Figure 12. Existing residential building, typical HDB slab-block, used as the case study for LCC: (a) Typical upper storey floor plan [6,34]; (b) Site plan [6]; (c,d) PV integration on eastern end-wall and northern corridors (north-east view), with dark blue PV modules (c) [3,6] and colored PV modules (Kromatix modules) (d).

The results related to both east-north and east-west designs, shown in Tables A1-A4 in Appendix A, indicate that it is not easy to make the application of BAPV façade systems (e.g., as additional cladding) on existing buildings economically efficient in case no refurbishment cost replacement is assumed. However, in these cases where the BAPV application can replace a required façade refurbishment which is anyway due, then the investment is more economically viable in the instances where energy efficiency savings are included and, especially, for the analyzed east-west design, NPVs are becoming positive even under contestable price scenarios (see Figure 13 and Table A4 in Appendix A).

If the BAPV system illustrated in Figure 13 would not replace façade refurbishment cost, the NPV would be negative at SGD 68.5k (IRR at 1.3\%) under the most-likely contestable price scenario (see Table A3 in Appendix A). The following changes need to occur so that at least the initial investment including financing cost are earned back, either: (1) the initial cost to be reduced by $43 \%$, (2) the electricity price to remain stable at 16.7 SGD cents $/ \mathrm{kWh}$ for the next 30 years or (3) the area efficiency of PV modules under vertical position needs to be more than doubled (i.e., $+119 \%$ ). 


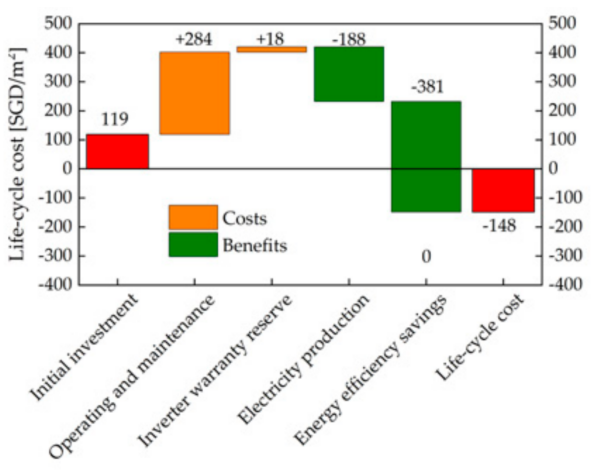

(a)

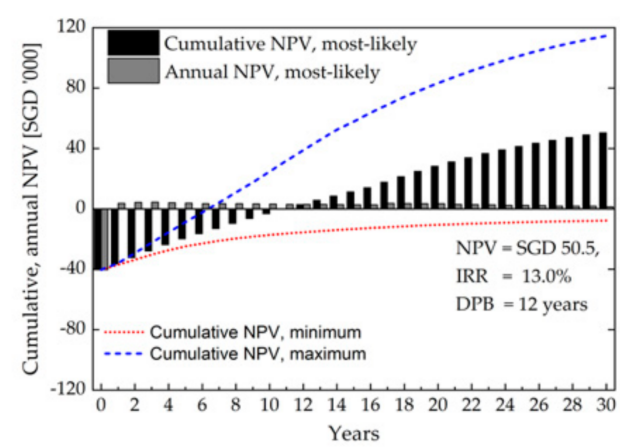

(b)

Figure 13. Life-cycle cost (LCC) assessment results for BAPV façade system (Kromatix modules) on the existing building with the east-west design using contestable power prices, $2{ }^{\circ} \mathrm{C}$ of energy efficiency savings and replaced refurbishment cost: (a) LCC $/ \mathrm{m}^{2}$ result using the most-likely price scenario; (b) Net Present Value (NPV) under the most-likely, minimum or maximum contestable price scenario.

The energy production is definitely the largest problem to make an attached vertical solar installation economic viable, as even in the "best", non-shaded location, the irradiance captured in a country close to the equator is $\sim 45 \%$ of what can be harnessed if the installation is horizontally installed. Due to additional critical technical aspects regarding waterproofing and safety issues, the application of PV as an additional cladding system within the retrofitting process may not be a general highly recommended strategy. However, given that economics is not the only relevant aspect in decision making, all solutions of this type should not be automatically excluded from considerations. Especially in the case of façades with a high degree of integrability (e.g., shading-free, large areas with no windows, etc.), and with a great need for improvement of the aesthetic aspect of the façade with the utilization of green technology; or in the projects in which cost-effectiveness does not play the most important role. Moreover, the installation of tilted PV modules directly contributes to the techno-economic performance. In addition, the scaling benefit, in cases when multiple buildings are retrofitted together and a supportive financing structure is in place, has not been considered in the performed calculations.

LCC assessment for BIPV façade system as a cladding system on a new hypothetical building-Case study 2 .

The economic results presented in Figure 14 and Table A5 (east-north design) and Table A6 (east-west design) in Appendix A, illustrate better economic performance for BIPV façade system for new buildings compared to BAPV replacing façade refurbishment in existing buildings, in most of the cases where additional energy efficiency benefits are included. The two cases only differ by the lower discount rate used for BIPV applications. Hence the same system configuration as shown in Figure 13 under BIPV application results in slightly better NPV and discounted payback time (Figure 14).

Based on the LCC results for BIPV façade system as a cladding system on a new building, including energy efficiency benefits, it can be concluded that new buildings and facilities should use BIPV façades as replacement for conventional façade materials. Where functional-aesthetic requirements allow, the application of PV modules with higher efficiency and the impact of scaling (in case multiple buildings are designed together potentially resulted in reduced costs) results in an even greater cost-effectiveness.

The performed LCC assessments for both case studies demonstrated potentials of PV façade systems. Performing further LCC analysis for different façade solutions, including both BIPV and BAPV on existing and new buildings, with PV modules of different levels of efficiency and transparency could help in increasing awareness and defining design guidelines for utilization of PV modules for different buildings and designs with different requirements in terms of functionality, aesthetic, visual and thermal point of view. 


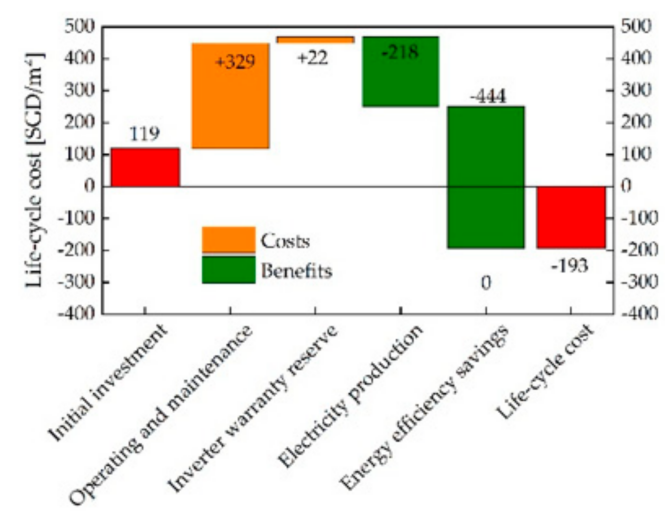

(a)

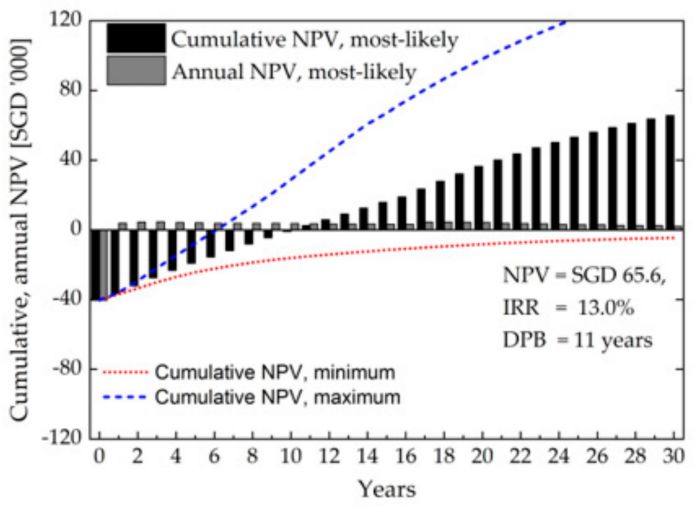

(b)

Figure 14. Life-cycle cost (LCC) assessment results for BIPV façade system (Kromatix modules) on a hypothetical new building with the east-west design using contestable power prices and $2{ }^{\circ} \mathrm{C}$ of energy efficiency benefits: (a) $\mathrm{LCC} / \mathrm{m}^{2}$ results; (b) Net Present Value (NPV) under the most-likely, minimum or maximum contestable price scenario.

Potential of PV Roof Integration

Due to the possibility of optimal positioning of PV modules and lower shading problems, PV roof integration is expected to be already commercially viable. This can be illustrated by the standard BAPV rooftop systems in Singapore of 203.9 MWp successfully installed by the private sector on pure commercial terms and the 170.8 MWp systems installed on government buildings, supported by the SolarNova program, as of the 2nd quarter of 2020 [55]. However, not all buildings are suitable for these standard BAPV systems, especially if the size is too small to make them economically feasible for investors. Hence there is a potential for BIPV on rooftops where other utility installations are using space and/or other alternatives are installed (i.e., carport, rooftop gardens, etc.).

The results of a recently performed door-to-door survey among the residents of HDB buildings, in which residents were asked to indicate which location they find most suitable for a mini-garden, whereby they were able to choose among five options: (a) on the ground floor of the building, (b) in a community garden near the building, (c) on the rooftop of the building, (d) on their floor (the corridor/the window ledge) and (e) inside the apartment, show that the rooftop is the second-ranked option, immediately after their floor [34]. However, although such solutions are not currently feasible for the rooftops of the existing HDB housing blocks, primarily not designed for utilization by the residents or public, these results certainly encourage the use of PV garden canopies on other types of buildings, including new buildings. Seen as important or very important by $75 \%$ of survey respondents, PV garden canopies, properly designed to protect people and plants from the sun, could be a good answer both to energy- and gardening-related needs.

LCC assessment for the roof canopy-Case study 3.

As outlined above, the higher energy yield is contributing to increased economic returns of PV modules installed horizontally. The calculations are performed for the three cases, including installation on only one building $\left(\sim 400 \mathrm{~m}^{2}\right)$, five $\left(\sim 2000 \mathrm{~m}^{2}\right)$ and ten buildings $\left(\sim 4000 \mathrm{~m}^{2}\right)$ combined. The results for all three scenarios are presented in Table A7 in Appendix A. Figure 15 illustrates the LCC and NPV for BIPV modules integrated into an existing canopy structure (the structural cost has not been included in the initial investment cost, assuming that five buildings can be done combined, i.e., $2000 \mathrm{~m}^{2}$ covered).

Both existing - if possible - and new buildings should have PV installations on the roof, cost-effective to the greatest possible extent, either as roof garden canopies, other canopies or as a PV surface installed on the roof as BIPV or BAPV, so the roof can accommodate as large as possible PV surface. 


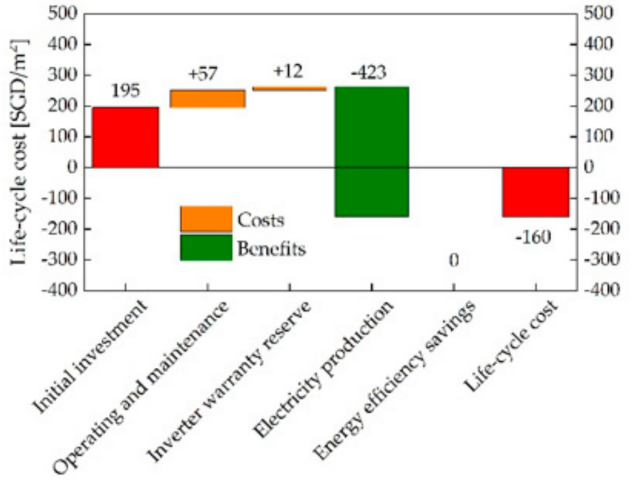

(a)

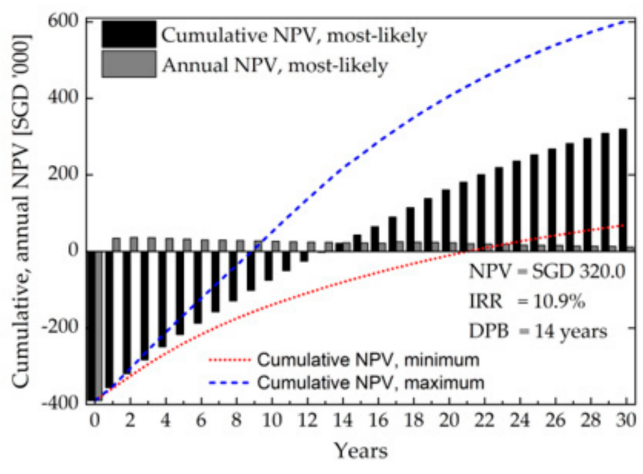

(b)

Figure 15. Life-cycle cost (LCC) assessment results for PV canopy (using $380 \mathrm{Wp}$ PERC Double-Glass modules) on an existing or a new building excluding any energy efficiency benefits and using contestable power prices: (a) LCC $/ \mathrm{m}^{2}$ results; (b) Net Present Value (NPV), under the most-likely, minimum or maximum contestable price scenario (structure cost not included).

\section{Conclusions}

Despite the constant increase of installed PV and intensive government effort towards "solarizations", implementation of PV and especially BIPV into the Singapore's built environment has not gathered as much momentum as would have been expected given the country's ample solar energy resource potential, strong economic fundamentals and the strong real estate sector.

At the outset of the study, a web-survey was conducted among local professionals in order to identify: (1) obstacles, (2) potentials and drivers that could facilitate and accelerate BIPV implementation and PV façade integration as well as (3) stakeholders' needs related to PV building integration that could encourage wider PV use in Singapore. However, the analysis of web-survey results, supported with qualitative face-to-face interviews with PV experts conducted after the web-survey, revealed that there is a significant gap between stakeholders in understanding PV integration. The following disputable issues were recognized: (1) incomplete understanding of BIPV and BAPV among stakeholders, (2) costs of BIPV systems, (3) low awareness of and confidence in "integrability" of PV modules, (4) incomplete knowledge about and insufficiently investigated PV performance and (5) potentials of PV façade and roof integration.

Respondents identified costs as the most critical general obstacle to widespread implementation of BIPV in Singapore. However, we have performed LLC assessment for three different PV integration cases in Singapore. The results indicated that it is not easy to make the application of BAPV façade systems (e.g., as additional cladding) on existing buildings economically efficient in case no refurbishment cost replacement is assumed. However, in those cases where BAPV application can replace the required façade refurbishment which is anyway due, the investment is more economically viable in instances where energy efficiency savings are included and, especially, for the analyzed east-west design, NPVs are becoming positive even under contestable price scenarios. PV façade integration as BIPV cladding on new buildings showed a satisfactory economic performance. Besides BIPV façade implementation on new buildings, the study encourages performing LCC assessments and searching optimal solutions for various other PV façade integrations, including applications in the form of cladding, shading devices, productive façades implementing both PV and vertical farming systems [7], etc., on existing buildings, too. Benefits of installing PV modules as a cladding on façade walls or shading devices on corridors, balconies or windows on existing HDB buildings as well as their potentials in improving indoor comfort quality should be investigated urgently.

Rooftop BIPV canopy, on both existing and new buildings, shows good economic performance. Moreover, the examined LCC assessment for the scenarios with one, five 
and ten buildings indicated that increased returns are possible in cases where there are additional benefits from economies of scale (i.e., canopy installed on ten buildings combined instead of just on a single one). This study encourages exploration of various possibilities of BIPV canopy implementation into the built environment (e.g., rooftop canopies, shelters over open space, walkways, etc.).

The results indicate that costs are not the only and maybe even not the major obstacle and that the problem of PV integration in Singapore is much wider and more complex. In that context, the findings reveal that the proper information flow, i.e., exchange and interconnections between stakeholders, processes and activities both in the PV integration sector and between this sector and the construction industry are among the key missing components for the strong growth of BIPV and other PV projects. Considering relevant environmental, economic and social factors, all findings related to the both hindering and facilitating factors given in this paper present the fundaments based on which a practical solution for identified problems in the form of a holistic strategy is developed and presented in the subsequent publication. Consisting of two mutually interconnected frameworks: (1) multilevel mechanism framework and (2) general design framework, addressing the identified factors and jointly creating a fertile ground for long-term stimulating and boosting of BIPV and other PV integrations, the strategy should help Singapore reduce the dependency on gas power generation, and achieve the national climate change targets, thus generally promoting a more sustainable built environment.

Author Contributions: Project's principal investigator participated in the project administration and supervision, conceptualization of the project, definition of methodology, writing, editing and review, S.-K.L.; definition of methodology, development of frameworks, writing, visualization and review, V.K.; LCC assessments and writing, M.B.; writing and review, A.M.N. All authors have read and agreed to the published version of the manuscript.

Funding: The authors wish to acknowledge the funding support by the research project "Evaluation and Development of Energy Efficient PV Systems in Tropical Environment" (WBS: R-294000-136-720), which is funded by the NUS-CDL Tropical Technology Laboratory (T2 Lab) and City Development Limited.

Institutional Review Board Statement: The NUS Institutional Review Board (NUS-IRB) has approved the ethical aspects of our research (Survey on Potentials, Barriers and Needs of Façade and Roof PV (Photovoltaic) Building Integration into Buildings in Singapore) based on our declaration and the IRB Exemption Form submitted (NUS-IRB Reference Code: S-18-101E).

Informed Consent Statement: Informed consent was obtained from all subjects involved in the study.

Data Availability Statement: The data that support the findings of this study are available from the corresponding author upon reasonable request.

Acknowledgments: The authors would like to thank the Department of Architecture, School of Design and Environment, National University of Singapore for the support for this project. The authors would also like to thank Christophe Inglin (Energetix Pte Ltd., Singapore) and Philip Kwang (Facade Global Master Pte Ltd., Singapore) for their professional assistance and support. The authors would also like to thank Abel Tablada and Zdravko Trivic for their professional advice. The authors would like to thank Dejan Jevtic for his professional assistance in the graphic preparation of the figures. The authors wish to express their sincere gratitude to all architects, PV experts and other professionals in Singapore who took part in the web-survey and qualitative interviews.

Conflicts of Interest: The authors declare no conflict of interest. The funders had no role in the design of the study; in the collection, analyses, or interpretation of data; in the writing of the manuscript, or in the decision to publish the results.

\section{Abbreviations}

List of Abbreviations: BAPV—building-applied photovoltaics; BIPV—building-integrated photovoltaics; DPB—discounted payback period; EMA—Energy Market Authority; HDB—Housing \& Development Board; IRR-Internal Rate of Return; LCC—-life-cycle cost; LNG_liquefied natural 
gas; MLPE—module level power electronics; NPV—Net Present Value; PERC—Passivated Emitter Rear Cell; PV—photovoltaic; SERIS—Solar Energy Research Institute of Singapore; USEP—Uniform

Singapore Energy Price.

Appendix A

\section{Respondents for whom costs are not among top 3 obstacles to BIPV}

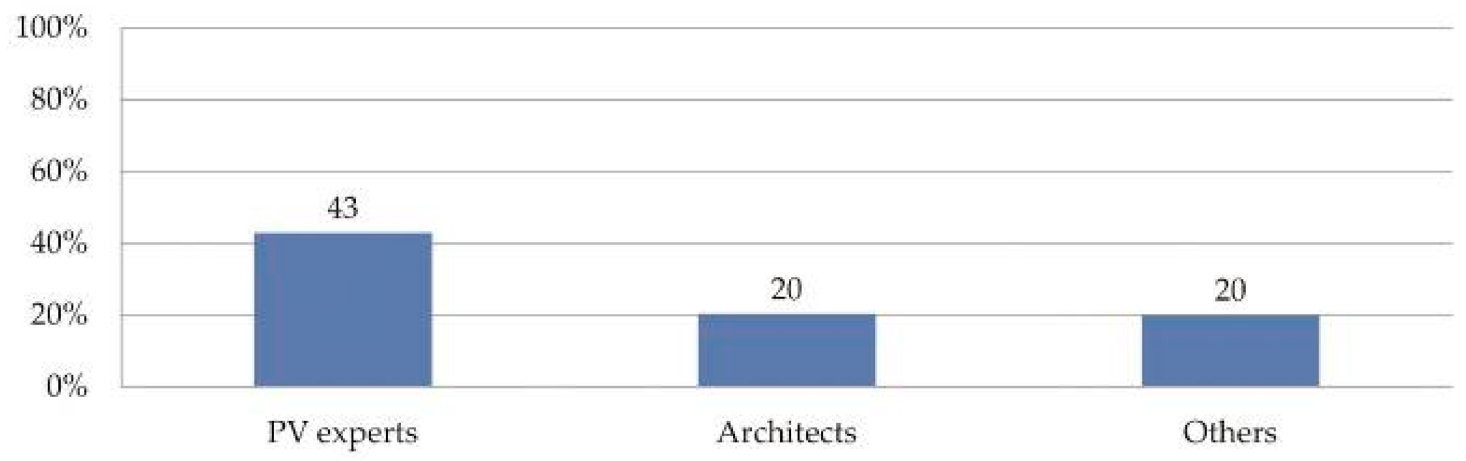

Figure 1. Share of respondents for whom costs are not among top 3 obstacles to BIPV in Singapore.

\section{Respondents for whom shading effect is among top 2 obstacles to implementation of BIPV}

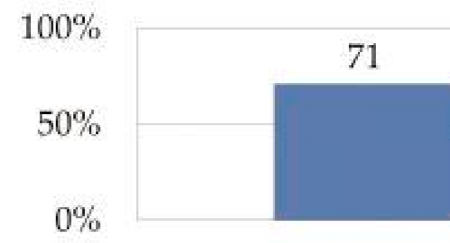

PV experts

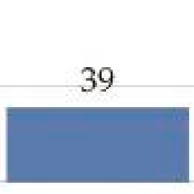

Architects
66

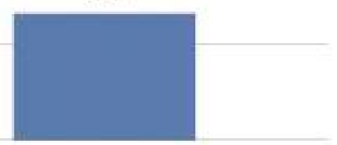

Other

Figure A2. Share of respondents for whom shading effect is among top 2 obstacles to BIPV in Singapore.

Table A1. Life-Cycle Cost (LCC) results for BAPV façade as additional cladding on an existing building with an eastnorth design, without refurbishment cost replacement (IRR-Internal Rate of Return, DPB-Discounted Payback, NPV-Net Present Value).

\begin{tabular}{|c|c|c|c|c|c|c|c|c|c|c|c|c|}
\hline \multicolumn{13}{|c|}{$\begin{array}{c}\text { BAPV Façade as Additional Cladding on Existing Building (PV Total: } 640 \mathrm{~m}^{2}=470 \mathrm{~m}^{2}(\text { North })+170 \mathrm{~m}^{2}(\text { East)); } 5.2 \% \text { Discount Rate, }(\text { System } \\
\text { Lifetime: } 30 \text { Years, Annual Degradation Rate: } 0.7 \% \text {, Inflation Rate: } 2 \%)\end{array}$} \\
\hline Energy Saving Scenarios & \multicolumn{4}{|c|}{ (1) no additional energy savings } & \multicolumn{4}{|c|}{ (2) 1-degree energy savings } & \multicolumn{4}{|c|}{ (3) 2-degrees energy savings } \\
\hline Electricity Price Customer & \multicolumn{2}{|c|}{ Non-contestable } & \multicolumn{2}{|c|}{ Contestable } & \multicolumn{2}{|c|}{ Non-contestable } & \multicolumn{2}{|c|}{ Contestable } & \multicolumn{2}{|c|}{ Non-contestable } & \multicolumn{2}{|c|}{ Contestable } \\
\hline Module type & AGC & Kromatix & AGC & Kromatix & AGC & Kromatix & AGC & Kromatix & AGC & Kromatix & AGC & Kromatix \\
\hline $\begin{array}{l}\text { Blended irradiance } \\
\left(\mathrm{kWh} / \mathrm{m}^{2}\right)\end{array}$ & 735 & 735 & 735 & 735 & 735 & 735 & 735 & 735 & 735 & 735 & 735 & 735 \\
\hline Area factor $\left(\mathrm{Wp} / \mathrm{m}^{2}\right)$ & 156 & 170 & 156 & 170 & 156 & 170 & 156 & 170 & 156 & 170 & 156 & 170 \\
\hline Installed capacity $(\mathrm{kWp})$ & 100 & 109 & 100 & 109 & 100 & 109 & 100 & 109 & 100 & 109 & 100 & 109 \\
\hline Cost per area $\left(\mathrm{SGD} / \mathrm{m}^{2}\right)$ & 548 & 469 & 548 & 469 & 548 & 469 & 548 & 469 & 548 & 469 & 548 & 469 \\
\hline $\begin{array}{l}\text { System installation cost } \\
\text { (SGD) }\end{array}$ & 350,555 & 299,922 & 350,555 & 299,922 & 350,555 & 299,922 & 350,555 & 299,922 & 350,555 & 299,922 & 350,555 & 299,922 \\
\hline Annual O\&M (SGD) & 9602 & 9602 & 9602 & 9602 & 9602 & 9602 & 9602 & 9602 & 9602 & 9602 & 9602 & 9602 \\
\hline
\end{tabular}


Table A1. Cont.

\begin{tabular}{|c|c|c|c|c|c|c|c|c|c|c|c|c|c|c|}
\hline \multicolumn{15}{|c|}{ BAPV Façade as Additio } \\
\hline \multicolumn{3}{|c|}{ Annual O\&M (SGD/m²) } & 5 & 5 & 5 & 5 & 5 & 5 & 5 & 5 & 5 & 5 & 5 & 5 \\
\hline \multicolumn{3}{|c|}{$\begin{array}{l}\text { Inverter Replacement } \\
\text { Reserve (SGD) }\end{array}$} & 968 & 1079 & 968 & 1079 & 968 & 1079 & 968 & 1079 & 968 & 1079 & 968 & 1079 \\
\hline \multicolumn{3}{|c|}{ Performance ratio (\%) } & $80 \%$ & $80 \%$ & $80 \%$ & $80 \%$ & $80 \%$ & $80 \%$ & $80 \%$ & $80 \%$ & $80 \%$ & $80 \%$ & $80 \%$ & $80 \%$ \\
\hline \multicolumn{3}{|c|}{ Specific yield (kWh/kWp) } & 588 & 588 & 588 & 588 & 588 & 588 & 588 & 588 & 588 & 588 & 588 & 588 \\
\hline \multicolumn{3}{|c|}{ 1st year generation $(\mathrm{kWh})$} & 58,785 & 63,958 & 58,785 & 63,958 & 58,785 & 63,958 & 58,785 & 63,958 & 58,785 & 63,958 & 58,785 & 63,958 \\
\hline \multicolumn{3}{|c|}{$\begin{array}{l}\text { Electricity Grid Emission } \\
\text { Factor }\left(\mathrm{CO}_{2} \mathrm{~g} / \mathrm{kWh}\right)\end{array}$} & 392 & 392 & 392 & 392 & 392 & 392 & 392 & 392 & 392 & 392 & 392 & 392 \\
\hline \multicolumn{3}{|c|}{$\begin{array}{l}\text { Savings of replaced } \\
\text { material (SGD) }\end{array}$} & - & - & - & - & - & - & - & - & - & - & - & - \\
\hline \multicolumn{3}{|c|}{ Net Investment } & 548 & 469 & 548 & 469 & 548 & 469 & 548 & 469 & 548 & 469 & 548 & 469 \\
\hline \multicolumn{3}{|c|}{$\begin{array}{l}\text { Operating and } \\
\text { maintenance }\end{array}$} & 284 & 284 & 284 & 284 & 284 & 284 & 284 & 284 & 284 & 284 & 284 & 284 \\
\hline \multicolumn{3}{|c|}{$\begin{array}{c}\text { Inverter } \\
\text { Replacement }\end{array}$} & 16 & 18 & 16 & 18 & 16 & 18 & 16 & 18 & 16 & 18 & 16 & 18 \\
\hline \multicolumn{3}{|c|}{$\begin{array}{c}\text { Electricity } \\
\text { production- } \\
\text { benefit } \\
\text { (most-likely) }\end{array}$} & -250 & -272 & -155 & -169 & -250 & -272 & -155 & -169 & -250 & -272 & -155 & -169 \\
\hline \multirow[t]{4}{*}{$\begin{array}{l}\text { result } \\
(\text { SGD/ } \\
\left.\mathrm{m}^{2}\right)\end{array}$} & \multicolumn{2}{|c|}{$\begin{array}{c}\text { Energy } \\
\text { savings-benefit } \\
\text { (most-likely) }\end{array}$} & - & - & - & - & -161 & -161 & -101 & -101 & -322 & -322 & -202 & -202 \\
\hline & \multicolumn{2}{|c|}{$\begin{array}{c}\mathrm{LCC} / \mathrm{m}^{2} \\
\text { (most-likely } \\
\text { scenario) }\end{array}$} & 598 & 498 & 692 & 601 & 437 & 338 & 591 & 500 & 276 & 177 & 490 & 399 \\
\hline & \multicolumn{2}{|c|}{$\begin{array}{l}\mathrm{LCC} / \mathrm{m}^{2} \\
\text { (minimum } \\
\text { scenario) }\end{array}$} & 660 & 566 & 738 & 651 & 541 & 447 & 668 & 581 & 421 & 327 & 597 & 511 \\
\hline & \multicolumn{2}{|c|}{$\begin{array}{l}\mathrm{LCC} / \mathrm{m}^{2} \\
\text { (maximum } \\
\text { scenario) }\end{array}$} & 551 & 448 & 640 & 545 & 361 & 257 & 506 & 410 & 170 & 66 & 371 & 276 \\
\hline \multirow{3}{*}{\multicolumn{2}{|c|}{$\begin{array}{c}\text { Financial } \\
\text { metrics } \\
\text { (most-likely } \\
\text { scenario): }\end{array}$}} & $\begin{array}{l}\text { NPV } \\
\text { (SGD) }\end{array}$ & \multicolumn{2}{|c|}{$-382,582-319,066$} & \multicolumn{2}{|c|}{$-443,023-384,826$} & \multicolumn{2}{|c|}{$-279,569-216,052$} & \multicolumn{2}{|c|}{$-378,327-320,130$} & \multicolumn{2}{|c|}{$-176,555-113,039$} & \multicolumn{2}{|c|}{$-313,632-255,434$} \\
\hline & & $\begin{array}{c}\text { DPB } \\
\text { (years) }\end{array}$ & $\mathrm{n} / \mathrm{a}$ & $\mathrm{n} / \mathrm{a}$ & $\mathrm{n} / \mathrm{a}$ & $\mathrm{n} / \mathrm{a}$ & $\mathrm{n} / \mathrm{a}$ & $\mathrm{n} / \mathrm{a}$ & $\mathrm{n} / \mathrm{a}$ & $\mathrm{n} / \mathrm{a}$ & $\mathrm{n} / \mathrm{a}$ & $\mathrm{n} / \mathrm{a}$ & $\mathrm{n} / \mathrm{a}$ & $\mathrm{n} / \mathrm{a}$ \\
\hline & & $\begin{array}{l}\text { IRR } \\
(\%)\end{array}$ & $\mathrm{n} / \mathrm{a}$ & $\mathrm{n} / \mathrm{a}$ & $\mathrm{n} / \mathrm{a}$ & $\mathrm{n} / \mathrm{a}$ & $\mathrm{n} / \mathrm{a}$ & $\mathrm{n} / \mathrm{a}$ & $\mathrm{n} / \mathrm{a}$ & $\mathrm{n} / \mathrm{a}$ & $\mathrm{n} / \mathrm{a}$ & $1.2 \%$ & $\mathrm{n} / \mathrm{a}$ & $\mathrm{n} / \mathrm{a}$ \\
\hline \multirow{3}{*}{\multicolumn{2}{|c|}{$\begin{array}{c}\text { Financial } \\
\text { metrics } \\
\text { (minimum } \\
\text { scenario): }\end{array}$}} & \multicolumn{3}{|c|}{ NPV(SGD)-422,585-362,589 } & \multicolumn{2}{|c|}{$-472,500-416,897$} & \multicolumn{2}{|c|}{$-346,034-286,038$} & \multicolumn{2}{|c|}{$-427,447-371,844$} & -269, & $3-209,486$ & $-382,3$ & $4-326,790$ \\
\hline & & $\begin{array}{c}\mathrm{DPB} \\
\text { (years) }\end{array}$ & $\mathrm{n} / \mathrm{a}$ & $\mathrm{n} / \mathrm{a}$ & $\mathrm{n} / \mathrm{a}$ & $\mathrm{n} / \mathrm{a}$ & $\mathrm{n} / \mathrm{a}$ & $\mathrm{n} / \mathrm{a}$ & $\mathrm{n} / \mathrm{a}$ & $\mathrm{n} / \mathrm{a}$ & $\mathrm{n} / \mathrm{a}$ & $\mathrm{n} / \mathrm{a}$ & $\mathrm{n} / \mathrm{a}$ & $\mathrm{n} / \mathrm{a}$ \\
\hline & & $\begin{array}{l}\text { IRR } \\
(\%)\end{array}$ & $\mathrm{n} / \mathrm{a}$ & $\mathrm{n} / \mathrm{a}$ & $\mathrm{n} / \mathrm{a}$ & $\mathrm{n} / \mathrm{a}$ & $\mathrm{n} / \mathrm{a}$ & $\mathrm{n} / \mathrm{a}$ & $\mathrm{n} / \mathrm{a}$ & $\mathrm{n} / \mathrm{a}$ & $\mathrm{n} / \mathrm{a}$ & $\mathrm{n} / \mathrm{a}$ & $\mathrm{n} / \mathrm{a}$ & $\mathrm{n} / \mathrm{a}$ \\
\hline $\begin{array}{r}\text { Fin } \\
\mathrm{me}\end{array}$ & & $\begin{array}{l}\text { NPV } \\
\text { (SGD) }\end{array}$ & -352, & $3-286,840$ & $-409,7$ & $-348,657$ & -230 & $9-164,656$ & $-323,6$ & $7-262,544$ & -108, & $6-42,473$ & $-237,5$ & $3-176,430$ \\
\hline $\begin{aligned}(\max \\
\text { scer }\end{aligned}$ & ium & $\begin{array}{c}\mathrm{DPB} \\
\text { (years) }\end{array}$ & $\mathrm{n} / \mathrm{a}$ & $\mathrm{n} / \mathrm{a}$ & $\mathrm{n} / \mathrm{a}$ & $\mathrm{n} / \mathrm{a}$ & $\mathrm{n} / \mathrm{a}$ & $\mathrm{n} / \mathrm{a}$ & $\mathrm{n} / \mathrm{a}$ & $\mathrm{n} / \mathrm{a}$ & $\mathrm{n} / \mathrm{a}$ & $\mathrm{n} / \mathrm{a}$ & $\mathrm{n} / \mathrm{a}$ & $\mathrm{n} / \mathrm{a}$ \\
\hline & & $\begin{array}{l}\text { IRR } \\
(\%)\end{array}$ & $\mathrm{n} / \mathrm{a}$ & $\mathrm{n} / \mathrm{a}$ & $\mathrm{n} / \mathrm{a}$ & $\mathrm{n} / \mathrm{a}$ & $\mathrm{n} / \mathrm{a}$ & $\mathrm{n} / \mathrm{a}$ & $\mathrm{n} / \mathrm{a}$ & $\mathrm{n} / \mathrm{a}$ & $2.1 \%$ & $3.8 \%$ & $\mathrm{n} / \mathrm{a}$ & $\mathrm{n} / \mathrm{a}$ \\
\hline $\begin{array}{r}\mathrm{CO}_{2} \\
\text { lif }\end{array}$ & $\begin{array}{l}\text { vings } \\
\text { me (t }\end{array}$ & $\begin{array}{l}\text { er the } \\
\text { es) }\end{array}$ & 621 & 675 & 621 & 675 & 1112 & 1167 & 1112 & 1167 & 1604 & 1658 & 1604 & 1658 \\
\hline
\end{tabular}


Table A2. Life-Cycle Cost (LCC) results for BAPV façade as additional cladding on an existing building with an eastnorth design, with refurbishment cost replacement (IRR-Internal Rate of Return, DPB-Discounted Payback, NPV-Net Present Value).

BAPV Façade as Additional Cladding on Existing Building (PV Total: $640 \mathrm{~m}^{2}=470 \mathrm{~m}^{2}$ (North) $+170 \mathrm{~m}^{2}$ (East)); $5.2 \%$ Discount Rate, (SYSTEM Lifetime: 30 Years, Annual Degradation Rate: 0.7\%, Inflation Rate: 2\%)

\begin{tabular}{|c|c|c|c|c|c|c|c|c|c|c|c|c|c|c|}
\hline \multirow{2}{*}{\multicolumn{3}{|c|}{$\begin{array}{l}\text { Energy Saving Scenarios } \\
\text { Electricity Price Customer }\end{array}$}} & \multicolumn{4}{|c|}{ (1) no additional energy savings } & \multicolumn{4}{|c|}{ (2) 1-degree energy savings } & \multicolumn{4}{|c|}{ (3) 2-degrees energy savings } \\
\hline & & & \multicolumn{2}{|c|}{ Non-contestable } & \multicolumn{2}{|c|}{ Contestable } & \multicolumn{2}{|c|}{ Non-contestable } & \multicolumn{2}{|c|}{ Contestable } & \multicolumn{2}{|c|}{ Non-contestable } & \multicolumn{2}{|c|}{ Contestable } \\
\hline \multicolumn{3}{|c|}{ Module type } & AGC & Kromatix & AGC & Kromatix & AGC & Kromatix & AGC & Kromatix & AGC & Kromatix & AGC & Kromatix \\
\hline \multicolumn{3}{|c|}{$\begin{array}{l}\text { Blended irradiance } \\
\quad\left(\mathrm{kWh} / \mathrm{m}^{2}\right)\end{array}$} & 735 & 735 & 735 & 735 & 735 & 735 & 735 & 735 & 735 & 735 & 735 & 735 \\
\hline \multicolumn{3}{|c|}{ Area factor $\left(\mathrm{Wp} / \mathrm{m}^{2}\right)$} & 156 & 170 & 156 & 170 & 156 & 170 & 156 & 170 & 156 & 170 & 156 & 170 \\
\hline \multicolumn{3}{|c|}{ Installed capacity (kWp) } & 100 & 109 & 100 & 109 & 100 & 109 & 100 & 109 & 100 & 109 & 100 & 109 \\
\hline \multicolumn{3}{|c|}{ Cost per area $\left(\mathrm{SGD} / \mathrm{m}^{2}\right)$} & 548 & 469 & 548 & 469 & 548 & 469 & 548 & 469 & 548 & 469 & 548 & 469 \\
\hline \multicolumn{3}{|c|}{$\begin{array}{c}\text { System installation cost } \\
\text { (SGD) }\end{array}$} & 350,555 & 299,922 & 350,555 & 299,922 & 350,555 & 299,922 & 350,555 & 299,922 & 350,555 & 299,922 & 350,555 & 299,922 \\
\hline \multicolumn{3}{|c|}{ Annual O\&M (SGD) } & 9602 & 9602 & 9602 & 9602 & 9602 & 9602 & 9602 & 9602 & 9602 & 9602 & 9602 & 9602 \\
\hline \multicolumn{3}{|c|}{ Annual O\&M (SGD/m²) } & 5 & 5 & 5 & 5 & 5 & 5 & 5 & 5 & 5 & 5 & 5 & 5 \\
\hline \multicolumn{3}{|c|}{$\begin{array}{l}\text { Inverter Replacement } \\
\text { Reserve (SGD) }\end{array}$} & 968 & 1079 & 968 & 1079 & 968 & 1079 & 968 & 1079 & 968 & 1079 & 968 & 1079 \\
\hline \multicolumn{3}{|c|}{ Performance ratio (\%) } & $80 \%$ & $80 \%$ & $80 \%$ & $80 \%$ & $80 \%$ & $80 \%$ & $80 \%$ & $80 \%$ & $80 \%$ & $80 \%$ & $80 \%$ & $80 \%$ \\
\hline \multicolumn{3}{|c|}{ Specific yield (kWh/kWp) } & 588 & 588 & 588 & 588 & 588 & 588 & 588 & 588 & 588 & 588 & 588 & 588 \\
\hline \multicolumn{3}{|c|}{ 1st year generation (kWh) } & 58,785 & 63,958 & 58,785 & 63,958 & 58,785 & 63,958 & 58,785 & 63,958 & 58,785 & 63,958 & 58,785 & 63,958 \\
\hline \multicolumn{3}{|c|}{$\begin{array}{l}\text { Electricity Grid Emission } \\
\text { Factor }\left(\mathrm{CO}_{2} \mathrm{~g} / \mathrm{kWh}\right)\end{array}$} & 392 & 392 & 392 & 392 & 392 & 392 & 392 & 392 & 392 & 392 & 392 & 392 \\
\hline \multicolumn{3}{|c|}{$\begin{array}{c}\text { Replaced material } \\
\left(\mathrm{SGD} / \mathrm{m}^{2}\right)\end{array}$} & -350 & -350 & -350 & -350 & -350 & -350 & -350 & -350 & -350 & -350 & -350 & -350 \\
\hline \multicolumn{3}{|c|}{$\begin{array}{l}\text { Savings of replaced } \\
\text { material (SGD) }\end{array}$} & \multicolumn{2}{|c|}{$-224,035-224,035$} & \multicolumn{2}{|c|}{$-224,035-224,035$} & \multicolumn{2}{|c|}{$-224,035-224,035$} & $-224,03$ & $5-224,035$ & $-224,03$ & $5-224,035$ & $-224,035$ & $5-224,035$ \\
\hline & Net & estment & 198 & 119 & 198 & 119 & 198 & 119 & 198 & 119 & 198 & 119 & 198 & 119 \\
\hline & $\begin{array}{r}\text { Ope } \\
\text { ma }\end{array}$ & $\begin{array}{l}\text { ng and } \\
\text { nance }\end{array}$ & 284 & 284 & 284 & 284 & 284 & 284 & 284 & 284 & 284 & 284 & 284 & 284 \\
\hline & & $\begin{array}{l}\text { rter } \\
\text { ement }\end{array}$ & 16 & 18 & 16 & 18 & 16 & 18 & 16 & 18 & 16 & 18 & 16 & 18 \\
\hline LCC & $\begin{array}{r}\mathrm{E} \\
\text { pro } \\
(\mathrm{mc}\end{array}$ & $\begin{array}{l}\text { icity } \\
\text { tion- } \\
\text { efit } \\
\text { likely) }\end{array}$ & -250 & -272 & -155 & -169 & -250 & -272 & -155 & -169 & -250 & -272 & -155 & -169 \\
\hline $\begin{array}{l}\text { result } \\
(\mathrm{SGD} / \\
\left.\mathrm{m}^{2}\right)\end{array}$ & $\begin{array}{r}\text { savi } \\
(\mathrm{mc}\end{array}$ & $\begin{array}{l}\text { rgy } \\
\text {-benefit } \\
\text { likely) }\end{array}$ & - & - & - & - & -161 & -161 & -101 & -101 & -322 & -322 & -202 & -202 \\
\hline & $\begin{array}{r}\mathrm{L} \\
(\mathrm{m} \\
\mathrm{S}\end{array}$ & $\begin{array}{l}\mathrm{m}^{2} \\
\text {-likely } \\
\text { ario) }\end{array}$ & 248 & 148 & 342 & 251 & 87 & -12 & 241 & 150 & -74 & -173 & 140 & 49 \\
\hline & & $\begin{array}{l}\mathrm{m}^{2} \\
\text { mum } \\
\text { ario) }\end{array}$ & 310 & 216 & 388 & 301 & 191 & 97 & 318 & 231 & 71 & -23 & 247 & 161 \\
\hline & & $\begin{array}{l}\mathrm{m}^{2} \\
\text { mum } \\
\text { ario) }\end{array}$ & 201 & 98 & 290 & 195 & 11 & -93 & 156 & 60 & -180 & -284 & 21 & -74 \\
\hline & & $\begin{array}{l}\text { NPV } \\
\text { (SGD) }\end{array}$ & $-158,54$ & $47-95,031$ & $-218,98$ & $8-160,791$ & $-55,534$ & 7983 & $-154,29$ & $2-96,095$ & 47,480 & 110,996 & $-89,597$ & $-31,399$ \\
\hline $\begin{array}{r}\mathrm{me} \\
(\mathrm{mos}\end{array}$ & trics & $\begin{array}{c}\text { DPB } \\
\text { (years) }\end{array}$ & $\mathrm{n} / \mathrm{a}$ & $\mathrm{n} / \mathrm{a}$ & $\mathrm{n} / \mathrm{a}$ & $\mathrm{n} / \mathrm{a}$ & $\mathrm{n} / \mathrm{a}$ & 22 & $\mathrm{n} / \mathrm{a}$ & $\mathrm{n} / \mathrm{a}$ & 17 & 6 & $\mathrm{n} / \mathrm{a}$ & $\mathrm{n} / \mathrm{a}$ \\
\hline & & $\begin{array}{l}\text { IRR } \\
(\%)\end{array}$ & $\mathrm{n} / \mathrm{a}$ & $\mathrm{n} / \mathrm{a}$ & $\mathrm{n} / \mathrm{a}$ & $\mathrm{n} / \mathrm{a}$ & $\mathrm{n} / \mathrm{a}$ & $6.4 \%$ & $\mathrm{n} / \mathrm{a}$ & $\mathrm{n} / \mathrm{a}$ & $8.7 \%$ & $18.2 \%$ & $\mathrm{n} / \mathrm{a}$ & $1.5 \%$ \\
\hline
\end{tabular}


Table A2. Cont.

\begin{tabular}{|c|c|c|c|c|c|c|c|c|c|c|c|c|c|}
\hline \multicolumn{14}{|c|}{$\begin{array}{l}\text { BAPV Façade as Additional Cladding on Existing Building (PV Total: } 640 \mathrm{~m}^{2}=470 \mathrm{~m}^{2} \text { (North) }+170 \mathrm{~m}^{2}(\text { East)); } 5.2 \% \text { Discount Rate, } \\
\text { (SYSTEM Lifetime: } 30 \text { Years, Annual Degradation Rate: } 0.7 \% \text {, Inflation Rate: } 2 \% \text { ) }\end{array}$} \\
\hline \multirow{3}{*}{$\begin{array}{l}\text { Financial } \\
\text { metrics } \\
\text { (minimum } \\
\text { scenario) }\end{array}$} & $\begin{array}{l}\text { NPV } \\
(\mathrm{SGD})\end{array}$ & \multicolumn{2}{|c|}{$-198,550-138,554$} & \multicolumn{2}{|c|}{$-248,465-192,862$} & \multicolumn{2}{|c|}{$-121,999-62,003$} & \multicolumn{2}{|c|}{$-203,412-147,809$} & \multirow{2}{*}{$\begin{array}{c}-45,448 \\
\mathrm{n} / \mathrm{a}\end{array}$} & \multirow{2}{*}{$\begin{array}{c}14,549 \\
12\end{array}$} & \multicolumn{2}{|c|}{$-158,359-102,755$} \\
\hline & $\begin{array}{c}\text { DPB } \\
\text { (years) }\end{array}$ & $\mathrm{n} / \mathrm{a}$ & $\mathrm{n} / \mathrm{a}$ & $\mathrm{n} / \mathrm{a}$ & $\mathrm{n} / \mathrm{a}$ & $\mathrm{n} / \mathrm{a}$ & $\mathrm{n} / \mathrm{a}$ & $\mathrm{n} / \mathrm{a}$ & $\mathrm{n} / \mathrm{a}$ & & & $\mathrm{n} / \mathrm{a}$ & $\mathrm{n} / \mathrm{a}$ \\
\hline & $\begin{array}{l}\text { IRR } \\
(\%)\end{array}$ & $\mathrm{n} / \mathrm{a}$ & $\mathrm{n} / \mathrm{a}$ & $\mathrm{n} / \mathrm{a}$ & $\mathrm{n} / \mathrm{a}$ & $\mathrm{n} / \mathrm{a}$ & $\mathrm{n} / \mathrm{a}$ & $\mathrm{n} / \mathrm{a}$ & $\mathrm{n} / \mathrm{a}$ & $\mathrm{n} / \mathrm{a}$ & $8.6 \%$ & $\mathrm{n} / \mathrm{a}$ & $\mathrm{n} / \mathrm{a}$ \\
\hline \multirow{3}{*}{$\begin{array}{l}\text { Financial } \\
\text { metrics } \\
\text { (maximum } \\
\text { scenario) }\end{array}$} & $\begin{array}{l}\text { NPV } \\
(\text { SGD) }\end{array}$ & -128 & $-62,805$ & -185 & $-124,622$ & -6744 & 59,379 & $-99,632$ & $-38,509$ & 115,439 & 181,562 & $-13,518$ & 47,605 \\
\hline & $\begin{array}{c}\text { DPB } \\
\text { (years) }\end{array}$ & $\mathrm{n} / \mathrm{a}$ & $\mathrm{n} / \mathrm{a}$ & $\mathrm{n} / \mathrm{a}$ & $\mathrm{n} / \mathrm{a}$ & $\mathrm{n} / \mathrm{a}$ & 11 & $\mathrm{n} / \mathrm{a}$ & $\mathrm{n} / \mathrm{a}$ & 11 & 5 & $\mathrm{n} / \mathrm{a}$ & 14 \\
\hline & $\begin{array}{l}\text { IRR } \\
(\%)\end{array}$ & $\mathrm{n} / \mathrm{a}$ & $\mathrm{n} / \mathrm{a}$ & $\mathrm{n} / \mathrm{a}$ & $\mathrm{n} / \mathrm{a}$ & $4.6 \%$ & $12.3 \%$ & $\mathrm{n} / \mathrm{a}$ & $\mathrm{n} / \mathrm{a}$ & $12.6 \%$ & $23.5 \%$ & $4.3 \%$ & $9.6 \%$ \\
\hline \multicolumn{2}{|c|}{$\begin{array}{c}\mathrm{CO}_{2} \text { savings over the } \\
\text { lifetime (tonnes) }\end{array}$} & 621 & 675 & 621 & 675 & 1112 & 1167 & 1112 & 1167 & 1604 & 1658 & 1604 & 1658 \\
\hline
\end{tabular}

Table A3. Life-Cycle Cost (LCC) results for BAPV façade as additional cladding on an existing building with an eastwest design, without refurbishment cost replacement (IRR-Internal Rate of Return, DPB-Discounted Payback, NPV-Net Present Value).

\begin{tabular}{|c|c|c|c|c|c|c|c|c|c|c|c|c|c|}
\hline \multicolumn{14}{|c|}{ BAPV Façade as Additional } \\
\hline \multirow{2}{*}{\multicolumn{2}{|c|}{$\begin{array}{c}\text { Energy Saving Scenarios } \\
\text { Electricity Price Customer }\end{array}$}} & \multicolumn{4}{|c|}{ (1) no additional energy savings } & \multicolumn{4}{|c|}{ (2) 1-degree energy savings } & \multicolumn{4}{|c|}{ (3) 2-degrees energy savings } \\
\hline & & \multicolumn{2}{|c|}{ Non-contestable } & \multicolumn{2}{|c|}{ Contestable } & \multicolumn{2}{|c|}{ Non-contestable } & \multicolumn{2}{|c|}{ Contestable } & \multicolumn{2}{|c|}{ Non-contestable } & \multicolumn{2}{|c|}{ Contestable } \\
\hline & Module type & AGC & Kromatix & AGC & Kromatix & AGC & Kromatix & AGC & Kromatix & AGC & Kromatix & AGC & Kromatix \\
\hline Ble & $\begin{array}{l}\text { ded irradiance } \\
\left(\mathrm{kWh} / \mathrm{m}^{2}\right)\end{array}$ & 817 & 817 & 817 & 817 & 817 & 817 & 817 & 817 & 817 & 817 & 817 & 817 \\
\hline Area & factor $\left(\mathrm{Wp} / \mathrm{m}^{2}\right)$ & 156 & 170 & 156 & 170 & 156 & 170 & 156 & 170 & 156 & 170 & 156 & 170 \\
\hline Install & ed capacity $(\mathrm{kWp})$ & 53 & 58 & 53 & 58 & 53 & 58 & 53 & 58 & 53 & 58 & 53 & 58 \\
\hline Cost $\mathrm{F}$ & er area $\left(\mathrm{SGD} / \mathrm{m}^{2}\right)$ & 548 & 469 & 548 & 469 & 548 & 469 & 548 & 469 & 548 & 469 & 548 & 469 \\
\hline Syste & $\begin{array}{l}\text { n installation cost } \\
\text { (SGD) }\end{array}$ & 186,203 & 159,309 & 186,203 & 159,309 & 186,203 & 159,309 & 186,203 & 159,309 & 186,203 & 159,309 & 186,203 & 159,309 \\
\hline Ann & ual O\&M (SGD) & 5100 & 5100 & 5100 & 5100 & 5100 & 5100 & 5100 & 5100 & 5100 & 5100 & 5100 & 5100 \\
\hline Annu & $1 \mathrm{O} \& \mathrm{M}\left(\mathrm{SGD} / \mathrm{m}^{2}\right)$ & 15 & 15 & 15 & 15 & 15 & 15 & 15 & 15 & 15 & 15 & 15 & 15 \\
\hline $\begin{array}{r}\text { Inve } \\
\mathrm{P}\end{array}$ & $\begin{array}{l}\text { ter Replacement } \\
\text { eserve (SGD) }\end{array}$ & 514 & 573 & 514 & 573 & 514 & 573 & 514 & 573 & 514 & 573 & 514 & 573 \\
\hline Perf & rmance ratio (\%) & $80 \%$ & $80 \%$ & $80 \%$ & $80 \%$ & $80 \%$ & $80 \%$ & $80 \%$ & $80 \%$ & $80 \%$ & $80 \%$ & $80 \%$ & $80 \%$ \\
\hline Specifi & yield $(\mathrm{kWh} / \mathrm{kWp})$ & 654 & 654 & 654 & 654 & 654 & 654 & 654 & 654 & 654 & 654 & 654 & 654 \\
\hline 1st yea & generation $(\mathrm{kWh})$ & 34,738 & 37,795 & 34,738 & 37,795 & 34,738 & 37,795 & 34,738 & 37,795 & 34,738 & 37,795 & 34,738 & 37,795 \\
\hline $\begin{array}{r}\text { Electri } \\
\text { Fact }\end{array}$ & $\begin{array}{l}\text { city Grid Emission } \\
\text { or }\left(\mathrm{CO}_{2} \mathrm{~g} / \mathrm{kWh}\right)\end{array}$ & 392 & 392 & 392 & 392 & 392 & 392 & 392 & 392 & 392 & 392 & 392 & 392 \\
\hline $\begin{array}{r}\text { Sav } \\
n\end{array}$ & $\begin{array}{l}\text { ngs of replaced } \\
\text { aterial (SGD) }\end{array}$ & - & - & - & - & - & - & - & - & - & - & - & - \\
\hline \multirow{3}{*}{$\begin{array}{c}\mathrm{LCC} \\
\text { result } \\
(\mathrm{SGD} / \\
\left.\mathrm{m}^{2}\right)\end{array}$} & Net Investment & 548 & 469 & 548 & 469 & 548 & 469 & 548 & 469 & 548 & 469 & 548 & 469 \\
\hline & $\begin{array}{c}\text { Operating and } \\
\text { maintenance }\end{array}$ & 284 & 284 & 284 & 284 & 284 & 284 & 284 & 284 & 284 & 284 & 284 & 284 \\
\hline & $\begin{array}{c}\text { Inverter } \\
\text { Replacement }\end{array}$ & 16 & 18 & 16 & 18 & 16 & 18 & 16 & 18 & 16 & 18 & 16 & 18 \\
\hline
\end{tabular}


Table A3. Cont.

\begin{tabular}{|c|c|c|c|c|c|c|c|c|c|c|c|c|c|c|}
\hline \multicolumn{15}{|c|}{ BAPV Façade as Additional $\mathrm{Cl}$} \\
\hline \multirow{5}{*}{$\begin{array}{l}\mathrm{LCC} \\
\text { result } \\
\text { (SGD/ } \\
\left.\mathrm{m}^{2}\right)\end{array}$} & \multicolumn{2}{|c|}{$\begin{array}{l}\text { Electricity } \\
\text { production- } \\
\text { benefit } \\
\text { (most-likely) }\end{array}$} & -278 & -302 & -173 & -188 & -278 & -302 & -173 & -188 & -278 & -302 & -173 & -188 \\
\hline & \multicolumn{2}{|c|}{$\begin{array}{c}\text { Energy } \\
\text { savings-benefit } \\
\text { (most-likely) }\end{array}$} & - & - & - & - & -303 & -303 & -190 & -190 & -606 & -606 & -381 & -381 \\
\hline & \multicolumn{2}{|c|}{$\begin{array}{c}\mathrm{LCC} / \mathrm{m}^{2} \\
\text { (most-likely } \\
\text { scenario) }\end{array}$} & 570 & 468 & 675 & 582 & 267 & 165 & 484 & 392 & -36 & -138 & 294 & 202 \\
\hline & \multicolumn{2}{|c|}{$\begin{array}{c}\mathrm{LCC} / \mathrm{m}^{2} \\
\text { (minimum } \\
\text { scenario) }\end{array}$} & 639 & 544 & 726 & 638 & 414 & 318 & 593 & 505 & 189 & 93 & 461 & 373 \\
\hline & \multicolumn{2}{|c|}{$\begin{array}{c}\mathrm{LCC} / \mathrm{m}^{2} \\
\text { (maximum } \\
\text { scenario) }\end{array}$} & 518 & 412 & 617 & 519 & 159 & 53 & 364 & 266 & -201 & -307 & 110 & 13 \\
\hline \multirow{3}{*}{\multicolumn{2}{|c|}{$\begin{array}{c}\text { Financial } \\
\text { metrics } \\
\text { (most-likely } \\
\text { scenario) }\end{array}$}} & $\begin{array}{l}\text { NPV } \\
\text { (SGD) }\end{array}$ & \multicolumn{2}{|c|}{$-193,657-159,078$} & \multicolumn{2}{|c|}{$-229,374-197,938$} & $-90,643$ & $-56,064$ & \multicolumn{2}{|c|}{$-164,678-133,242$} & 12,370 & 46,949 & $-99,982$ & $-68,547$ \\
\hline & & $\begin{array}{c}\mathrm{DPB} \\
\text { (years) }\end{array}$ & $\mathrm{n} / \mathrm{a}$ & $\mathrm{n} / \mathrm{a}$ & $\mathrm{n} / \mathrm{a}$ & $\mathrm{n} / \mathrm{a}$ & $\mathrm{n} / \mathrm{a}$ & $\mathrm{n} / \mathrm{a}$ & $\mathrm{n} / \mathrm{a}$ & $\mathrm{n} / \mathrm{a}$ & 26 & 19 & $\mathrm{n} / \mathrm{a}$ & $\mathrm{n} / \mathrm{a}$ \\
\hline & & $\begin{array}{l}\text { IRR } \\
(\%)\end{array}$ & $\mathrm{n} / \mathrm{a}$ & $\mathrm{n} / \mathrm{a}$ & $\mathrm{n} / \mathrm{a}$ & $\mathrm{n} / \mathrm{a}$ & $\mathrm{n} / \mathrm{a}$ & $1.5 \%$ & $\mathrm{n} / \mathrm{a}$ & $\mathrm{n} / \mathrm{a}$ & $5.8 \%$ & $7.7 \%$ & $0.1 \%$ & $1.3 \%$ \\
\hline \multirow{3}{*}{\multicolumn{2}{|c|}{$\begin{array}{c}\text { Financial } \\
\text { metrics } \\
\text { (minimum } \\
\text { scenario) }\end{array}$}} & $\begin{array}{l}\text { NPV } \\
\text { (SGD) }\end{array}$ & \multicolumn{2}{|c|}{$-217,296-184,797$} & \multicolumn{2}{|c|}{$-246,793-216,890$} & \multicolumn{2}{|c|}{$-140,745-108,246$} & \multicolumn{2}{|c|}{$-201,740-171,837$} & $-64,194$ & $-31,695$ & \multicolumn{2}{|c|}{$-156,686-126,783$} \\
\hline & & $\begin{array}{c}\mathrm{DPB} \\
\text { (years) }\end{array}$ & $\mathrm{n} / \mathrm{a}$ & $\mathrm{n} / \mathrm{a}$ & $\mathrm{n} / \mathrm{a}$ & $\mathrm{n} / \mathrm{a}$ & $\mathrm{n} / \mathrm{a}$ & $\mathrm{n} / \mathrm{a}$ & $\mathrm{n} / \mathrm{a}$ & $\mathrm{n} / \mathrm{a}$ & $\mathrm{n} / \mathrm{a}$ & $\mathrm{n} / \mathrm{a}$ & $\mathrm{n} / \mathrm{a}$ & $\mathrm{n} / \mathrm{a}$ \\
\hline & & $\begin{array}{l}\text { IRR } \\
(\%)\end{array}$ & $\mathrm{n} / \mathrm{a}$ & $\mathrm{n} / \mathrm{a}$ & $\mathrm{n} / \mathrm{a}$ & $\mathrm{n} / \mathrm{a}$ & $\mathrm{n} / \mathrm{a}$ & $\mathrm{n} / \mathrm{a}$ & $\mathrm{n} / \mathrm{a}$ & $\mathrm{n} / \mathrm{a}$ & $1.1 \%$ & $2.9 \%$ & $\mathrm{n} / \mathrm{a}$ & $\mathrm{n} / \mathrm{a}$ \\
\hline \multirow{3}{*}{\multicolumn{2}{|c|}{$\begin{array}{l}\text { Financial } \\
\text { metrics } \\
\text { (maximum } \\
\text { scenario) }\end{array}$}} & $\mathrm{NPV}(\mathrm{S}$ & D+176 & $-140,034$ & -209 & $-176,565$ & $-53,970$ & $-17,851$ & -123, & $-90,451$ & 68,213 & 104,332 & $-37,502$ & -4338 \\
\hline & & $\begin{array}{c}\mathrm{DPB} \\
\text { (years) }\end{array}$ & $\mathrm{n} / \mathrm{a}$ & $\mathrm{n} / \mathrm{a}$ & $\mathrm{n} / \mathrm{a}$ & $\mathrm{n} / \mathrm{a}$ & $\mathrm{n} / \mathrm{a}$ & $\mathrm{n} / \mathrm{a}$ & $\mathrm{n} / \mathrm{a}$ & $\mathrm{n} / \mathrm{a}$ & 17 & 14 & $\mathrm{n} / \mathrm{a}$ & $\mathrm{n} / \mathrm{a}$ \\
\hline & & $\begin{array}{l}\text { IRR } \\
(\%)\end{array}$ & $\mathrm{n} / \mathrm{a}$ & $\mathrm{n} / \mathrm{a}$ & $\mathrm{n} / \mathrm{a}$ & $\mathrm{n} / \mathrm{a}$ & $2.3 \%$ & $4.1 \%$ & $\mathrm{n} / \mathrm{a}$ & $\mathrm{n} / \mathrm{a}$ & $8.2 \%$ & $10.4 \%$ & $3.5 \%$ & $5.0 \%$ \\
\hline \multicolumn{3}{|c|}{$\begin{array}{l}\mathrm{CO}_{2} \text { savings over the } \\
\text { lifetime (tonnes) }\end{array}$} & 367 & 399 & 367 & 399 & 858 & 891 & 858 & 891 & 1350 & 1382 & 1350 & 1382 \\
\hline
\end{tabular}

Table A4. Life-Cycle Cost (LCC) results for BAPV façade as additional cladding on an existing building with an eastwest design, with refurbishment cost replacement (IRR-Internal Rate of Return, DPB-Discounted Payback, NPV-Net Present Value).

\begin{tabular}{|c|c|c|c|c|c|c|c|c|c|c|c|c|}
\hline \multirow{3}{*}{$\begin{array}{l}\text { Energy Saving Scenarios } \\
\text { lectricity Price Customer } \\
\text { Module type }\end{array}$} & \multicolumn{4}{|c|}{ (1) no additional energy savings } & \multicolumn{4}{|c|}{ (2) 1-degree energy savings } & \multicolumn{4}{|c|}{ (3) 2-degrees energy savings } \\
\hline & \multicolumn{2}{|c|}{ Non-contestable } & \multicolumn{2}{|c|}{ Contestable } & \multicolumn{2}{|c|}{ Non-contestable } & \multicolumn{2}{|c|}{ Contestable } & \multicolumn{2}{|c|}{ Non-contestable } & \multicolumn{2}{|c|}{ Contestable } \\
\hline & AGC & Kromatix & AGC & Kromatix & AGC & Kromatix & AGC & Kromatix & AGC & Kromatix & AGC & Kromati \\
\hline $\begin{array}{l}\text { Blended irradiance } \\
\left(\mathrm{kWh} / \mathrm{m}^{2}\right)\end{array}$ & 817 & 817 & 817 & 817 & 817 & 817 & 817 & 817 & 817 & 817 & 817 & 817 \\
\hline Area factor $\left(\mathrm{Wp} / \mathrm{m}^{2}\right)$ & 156 & 170 & 156 & 170 & 156 & 170 & 156 & 170 & 156 & 170 & 156 & 170 \\
\hline Installed capacity $(\mathrm{kWp})$ & 53 & 58 & 53 & 58 & 53 & 58 & 53 & 58 & 53 & 58 & 53 & 58 \\
\hline Cost per area (SGD/m2) & 548 & 469 & 548 & 469 & 548 & 469 & 548 & 469 & 548 & 469 & 548 & 469 \\
\hline $\begin{array}{l}\text { System installation cost } \\
\text { (SGD) }\end{array}$ & 186,203 & 159,309 & 186,203 & 159,309 & 186,203 & 159,309 & 186,203 & 159,309 & 186,203 & 159,309 & 186,203 & 159,309 \\
\hline Annual O\&M (SGD) & 5100 & 5100 & 5100 & 5100 & 5100 & 5100 & 5100 & 5100 & 5100 & 5100 & 5100 & 5100 \\
\hline
\end{tabular}


Table A4. Cont.

BAPV Façade System as Additional Cladding on Existing Building (PV Total: $340 \mathrm{~m}^{2}=170 \mathrm{~m}^{2}$ (West) $+170 \mathrm{~m}^{2}($ East)); $5.2 \%$ Discount Rate (System Lifetime: 30 Years, Annual Degradation Rate: 0.7\%, Inflation Rate: 2\%)

\begin{tabular}{|c|c|c|c|c|c|c|c|c|c|c|c|c|c|c|}
\hline \multicolumn{3}{|c|}{ Annual O\&M (SGD/m2) } & 15 & 15 & 15 & 15 & 15 & 15 & 15 & 15 & 15 & 15 & 15 & 15 \\
\hline \multicolumn{3}{|c|}{$\begin{array}{l}\text { Inverter Replacement } \\
\text { Reserve (SGD) }\end{array}$} & 514 & 573 & 514 & 573 & 514 & 573 & 514 & 573 & 514 & 573 & 514 & 573 \\
\hline \multicolumn{3}{|c|}{ Performance ratio (\%) } & $80 \%$ & $80 \%$ & $80 \%$ & $80 \%$ & $80 \%$ & $80 \%$ & $80 \%$ & $80 \%$ & $80 \%$ & $80 \%$ & $80 \%$ & $80 \%$ \\
\hline \multicolumn{3}{|c|}{ Specific yield (kWh/kWp) } & 654 & 654 & 654 & 654 & 654 & 654 & 654 & 654 & 654 & 654 & 654 & 654 \\
\hline \multicolumn{3}{|c|}{ 1st year generation (kWh) } & 34,738 & 37,795 & 34,738 & 37,795 & 34,738 & 37,795 & 34,738 & 37,795 & 34,738 & 37,795 & 34,738 & 37,795 \\
\hline \multicolumn{3}{|c|}{$\begin{array}{l}\text { Electricity Grid Emission } \\
\text { Factor }\left(\mathrm{CO}_{2} \mathrm{~g} / \mathrm{kWh}\right)\end{array}$} & 392 & 392 & 392 & 392 & 392 & 392 & 392 & 392 & 392 & 392 & 392 & 392 \\
\hline \multicolumn{3}{|c|}{$\begin{array}{c}\text { Replaced material } \\
\left(\mathrm{SGD} / \mathrm{m}^{2}\right)\end{array}$} & -350 & -350 & -350 & -350 & -350 & -350 & -350 & -350 & -350 & -350 & -350 & -350 \\
\hline \multicolumn{3}{|c|}{$\begin{array}{l}\text { Savings of replaced } \\
\text { material (SGD) }\end{array}$} & \multicolumn{2}{|c|}{$-119,000-119,000$} & \multicolumn{2}{|c|}{$-119,000-119,000$} & \multicolumn{2}{|c|}{$-119,000-119,000$} & \multicolumn{2}{|c|}{$-119,000-119,000$} & \multicolumn{2}{|c|}{$-119,000-119,000$} & \multicolumn{2}{|c|}{$-119,000-119,000$} \\
\hline \multirow{8}{*}{$\begin{array}{l}\mathrm{LCC} \\
\text { result } \\
(\mathrm{SGD} / \\
\left.\mathrm{m}^{2}\right)\end{array}$} & \multicolumn{2}{|c|}{ Net Investment } & 198 & 119 & 198 & 119 & 198 & 119 & 198 & 119 & 198 & 119 & 198 & 119 \\
\hline & \multicolumn{2}{|c|}{$\begin{array}{l}\text { Operating and } \\
\text { maintenance }\end{array}$} & 284 & 284 & 284 & 284 & 284 & 284 & 284 & 284 & 284 & 284 & 284 & 284 \\
\hline & \multicolumn{2}{|c|}{$\begin{array}{c}\text { Inverter } \\
\text { Replacement }\end{array}$} & 16 & 18 & 16 & 18 & 16 & 18 & 16 & 18 & 16 & 18 & 16 & 18 \\
\hline & \multicolumn{2}{|c|}{$\begin{array}{c}\text { Electricity } \\
\text { production- } \\
\text { benefit } \\
\text { (most-likely) }\end{array}$} & -278 & -302 & -173 & -188 & -278 & -302 & -173 & -188 & -278 & -302 & -173 & -188 \\
\hline & \multicolumn{2}{|c|}{$\begin{array}{c}\text { Energy } \\
\text { savings-benefit } \\
\text { (most-likely) }\end{array}$} & - & - & - & - & -303 & -303 & -190 & -190 & -606 & -606 & -381 & -381 \\
\hline & \multicolumn{2}{|c|}{$\begin{array}{l}\mathrm{LCC} / \mathrm{m}^{2} \\
\text { (most-likely } \\
\text { scenario) }\end{array}$} & 220 & 118 & 325 & 232 & -83 & -185 & 134 & 42 & -386 & -488 & -56 & -148 \\
\hline & \multicolumn{2}{|c|}{$\begin{array}{l}\mathrm{LCC} / \mathrm{m}^{2} \\
\text { (minimum } \\
\text { scenario) }\end{array}$} & 289 & 194 & 376 & 288 & 64 & -32 & 243 & 155 & -161 & -257 & 111 & 23 \\
\hline & \multicolumn{2}{|c|}{$\begin{array}{l}\mathrm{LCC} / \mathrm{m}^{2} \\
\text { (maximum } \\
\text { scenario) }\end{array}$} & 168 & 62 & 267 & 169 & -191 & -297 & 14 & -84 & -551 & -657 & -240 & -337 \\
\hline \multirow{3}{*}{\multicolumn{2}{|c|}{$\begin{array}{c}\text { Financial } \\
\text { metrics } \\
\text { (most-likely } \\
\text { scenario) }\end{array}$}} & $\begin{array}{l}\text { NPV } \\
(\mathrm{SGD})\end{array}$ & $-74,657$ & $-40,078$ & $-110,37$ & $4-78,938$ & 28,357 & 62,936 & $-45,678$ & $-14,242$ & 131,370 & 165,949 & 19,018 & 50,453 \\
\hline & & $\begin{array}{c}\text { DPB } \\
\text { (years) }\end{array}$ & $\mathrm{n} / \mathrm{a}$ & $\mathrm{n} / \mathrm{a}$ & $\mathrm{n} / \mathrm{a}$ & $\mathrm{n} / \mathrm{a}$ & 16 & 6 & $\mathrm{n} / \mathrm{a}$ & $\mathrm{n} / \mathrm{a}$ & 6 & 3 & 21 & 12 \\
\hline & & $\begin{array}{l}\text { IRR } \\
(\%)\end{array}$ & $\mathrm{n} / \mathrm{a}$ & $\mathrm{n} / \mathrm{a}$ & $\mathrm{n} / \mathrm{a}$ & $\mathrm{n} / \mathrm{a}$ & $9.1 \%$ & $19.1 \%$ & $\mathrm{n} / \mathrm{a}$ & $2.1 \%$ & $20.7 \%$ & $38.4 \%$ & $7.2 \%$ & $13.0 \%$ \\
\hline \multirow{3}{*}{\multicolumn{2}{|c|}{$\begin{array}{l}\text { Financial } \\
\text { metrics } \\
\text { (minimum } \\
\text { scenario) }\end{array}$}} & $\begin{array}{l}\mathrm{NPV} \\
(\mathrm{SGD})\end{array}$ & $-98,296$ & $-65,797$ & $-127,79$ & $3-97,890$ & $-21,745$ & 10,754 & $-82,740$ & $-52,837$ & 54,806 & 87,305 & $-37,686$ & -7783 \\
\hline & & $\begin{array}{c}\text { DPB } \\
\text { (years) }\end{array}$ & $\mathrm{n} / \mathrm{a}$ & $\mathrm{n} / \mathrm{a}$ & $\mathrm{n} / \mathrm{a}$ & $\mathrm{n} / \mathrm{a}$ & $\mathrm{n} / \mathrm{a}$ & 10 & $\mathrm{n} / \mathrm{a}$ & $\mathrm{n} / \mathrm{a}$ & 8 & 3 & $\mathrm{n} / \mathrm{a}$ & $\mathrm{n} / \mathrm{a}$ \\
\hline & & $\begin{array}{l}\text { IRR } \\
(\%)\end{array}$ & $\mathrm{n} / \mathrm{a}$ & $\mathrm{n} / \mathrm{a}$ & $\mathrm{n} / \mathrm{a}$ & $\mathrm{n} / \mathrm{a}$ & $\mathrm{n} / \mathrm{a}$ & $9.8 \%$ & $\mathrm{n} / \mathrm{a}$ & $\mathrm{n} / \mathrm{a}$ & $14.5 \%$ & $31.1 \%$ & $\mathrm{n} / \mathrm{a}$ & $2.7 \%$ \\
\hline \multirow{3}{*}{\multicolumn{2}{|c|}{$\begin{array}{l}\text { Financial } \\
\text { metrics } \\
\text { (maximum } \\
\text { scenario) }\end{array}$}} & $\begin{array}{l}\text { NPV } \\
\text { (SGD) }\end{array}$ & $-57,153$ & $-21,034$ & $-90,729$ & $-57,565$ & 65,030 & 101,149 & -4616 & 28,549 & 187,213 & 223,332 & 81,498 & 114,662 \\
\hline & & $\begin{array}{c}\text { DPB } \\
\text { (years) }\end{array}$ & $\mathrm{n} / \mathrm{a}$ & $\mathrm{n} / \mathrm{a}$ & $\mathrm{n} / \mathrm{a}$ & $\mathrm{n} / \mathrm{a}$ & 11 & 5 & $\mathrm{n} / \mathrm{a}$ & 14 & 5 & 3 & 11 & 7 \\
\hline & & $\begin{array}{l}\text { IRR } \\
(\%)\end{array}$ & $\mathrm{n} / \mathrm{a}$ & $\mathrm{n} / \mathrm{a}$ & $\mathrm{n} / \mathrm{a}$ & $\mathrm{n} / \mathrm{a}$ & $13.1 \%$ & $24.4 \%$ & $4.6 \%$ & $10.2 \%$ & $25.0 \%$ & $44.1 \%$ & $13.0 \%$ & $21.0 \%$ \\
\hline \multicolumn{3}{|c|}{$\begin{array}{l}\mathrm{CO}_{2} \text { savings over the } \\
\text { lifetime (tonnes) }\end{array}$} & 367 & 399 & 367 & 399 & 858 & 891 & 858 & 891 & 1350 & 1382 & 1350 & 1382 \\
\hline
\end{tabular}


Table A5. Life-Cycle Cost (LCC) results for BIPV façade as cladding system on a hypothetical new building with an east-north design (IRR-Internal Rate of Return, DPB-Discounted Payback, NPV-Net Present Value).

BIPV as Cladding System on New Building (PV Total: $640 \mathrm{~m}^{2}=470 \mathrm{~m}^{2}$ (North) $+170 \mathrm{~m}^{2}$ (East)), 4.0\% Discount Rate (System Lifetime: 30 Years, Annual Degradation Rate: 0.7\%, Inflation Rate: $2 \%$ )

\begin{tabular}{|c|c|c|c|c|c|c|c|c|c|c|c|c|c|}
\hline \multirow{3}{*}{\multicolumn{2}{|c|}{$\begin{array}{c}\text { Energy Saving Scenarios } \\
\text { Electricity Price Customer } \\
\text { Module type }\end{array}$}} & \multicolumn{4}{|c|}{ (1) no additional energy savings } & \multicolumn{4}{|c|}{ (2) 1-degree energy savings } & \multicolumn{4}{|c|}{ (3) 2-degrees energy savings } \\
\hline & & \multicolumn{2}{|c|}{ Non-contestable } & \multicolumn{2}{|c|}{ Contestable } & \multicolumn{2}{|c|}{ Non-contestable } & \multicolumn{2}{|c|}{ Contestable } & \multicolumn{2}{|c|}{ Non-contestable } & \multicolumn{2}{|c|}{ Contestable } \\
\hline & & AGC & Kromatix & AGC & Kromatix & AGC & Kromatix & AGC & Kromatix & AGC & Kromatix & AGC & Kromatix \\
\hline Blen & $\begin{array}{l}\text { ded irradiance } \\
\left(\mathrm{kWh} / \mathrm{m}^{2}\right)\end{array}$ & 735 & 735 & 735 & 735 & 735 & 735 & 735 & 735 & 735 & 735 & 735 & 735 \\
\hline Area & factor $\left(\mathrm{Wp} / \mathrm{m}^{2}\right)$ & 156 & 170 & 156 & 170 & 156 & 170 & 156 & 170 & 156 & 170 & 156 & 170 \\
\hline Installe & ed capacity $(\mathrm{kWp})$ & 100 & 109 & 100 & 109 & 100 & 109 & 100 & 109 & 100 & 109 & 100 & 109 \\
\hline Cost pe & er area $\left(\mathrm{SGD} / \mathrm{m}^{2}\right)$ & 548 & 469 & 548 & 469 & 548 & 469 & 548 & 469 & 548 & 469 & 548 & 469 \\
\hline System & $\begin{array}{l}\text { n installation cost } \\
\text { (SGD) }\end{array}$ & 350,555 & 299,922 & 350,555 & 299,922 & 350,555 & 299,922 & 350,555 & 299,922 & 350,555 & 299,922 & 350,555 & 299,922 \\
\hline Annt & ual O\&M (SGD) & 9602 & 9602 & 9602 & 9602 & 9602 & 9602 & 9602 & 9602 & 9602 & 9602 & 9602 & 9602 \\
\hline Annual & l O\&M (SGD/m²) & 15 & 15 & 15 & 15 & 15 & 15 & 15 & 15 & 15 & 15 & 15 & 15 \\
\hline $\begin{array}{r}\text { Inver } \\
\text { Re }\end{array}$ & $\begin{array}{l}\text { ter Replacement } \\
\text { eserve (SGD) }\end{array}$ & 968 & 1079 & 968 & 1079 & 968 & 1079 & 968 & 1079 & 968 & 1079 & 968 & 1079 \\
\hline Perfol & rmance ratio (\%) & $80 \%$ & $80 \%$ & $80 \%$ & $80 \%$ & $80 \%$ & $80 \%$ & $80 \%$ & $80 \%$ & $80 \%$ & $80 \%$ & $80 \%$ & $80 \%$ \\
\hline Specific & yield $(\mathrm{kWh} / \mathrm{kWp})$ & 588 & 588 & 588 & 588 & 588 & 588 & 588 & 588 & 588 & 588 & 588 & 588 \\
\hline 1st year & generation $(\mathrm{kWh})$ & 58,785 & 63,958 & 58,785 & 63,958 & 58,785 & 63,958 & 58,785 & 63,958 & 58,785 & 63,958 & 58,785 & 63,958 \\
\hline $\begin{array}{r}\text { Electric } \\
\text { Factc }\end{array}$ & $\begin{array}{l}\text { ity Grid Emission } \\
\text { or }\left(\mathrm{CO}^{2} \mathrm{~g} / \mathrm{kWh}\right)\end{array}$ & 392 & 392 & 392 & 392 & 392 & 392 & 392 & 392 & 392 & 392 & 392 & 392 \\
\hline Rep & $\begin{array}{l}\text { laced material } \\
\left(\mathrm{SGD} / \mathrm{m}^{2}\right)\end{array}$ & -350 & -350 & -350 & -350 & -350 & -350 & -350 & -350 & -350 & -350 & -350 & -350 \\
\hline $\begin{array}{r}\text { Savi } \\
\mathrm{m}\end{array}$ & $\begin{array}{l}\text { ngs of replaced } \\
\text { aterial (SGD) }\end{array}$ & $-224,03$ & $5-224,035$ & $-224,03$ & $5-224,035$ & $-224,035$ & $5-224,035$ & $-224,03$ & $5-224,035$ & $-224,035$ & $5-224,035$ & $-224,03$ & $5-224,035$ \\
\hline \multirow{8}{*}{$\begin{array}{l}\mathrm{LCC} \\
\text { result } \\
(\mathrm{SGD} / \\
\left.\mathrm{m}^{2}\right)\end{array}$} & Net Investment & 198 & 119 & 198 & 119 & 198 & 119 & 198 & 119 & 198 & 119 & 198 & 119 \\
\hline & $\begin{array}{l}\text { Operating and } \\
\text { maintenance }\end{array}$ & 329 & 329 & 329 & 329 & 329 & 329 & 329 & 329 & 329 & 329 & 329 & 329 \\
\hline & $\begin{array}{c}\text { Inverter } \\
\text { Replacement }\end{array}$ & 19 & 22 & 19 & 22 & 19 & 22 & 19 & 22 & 19 & 22 & 19 & 22 \\
\hline & $\begin{array}{l}\text { Electricity } \\
\text { production- } \\
\text { benefit } \\
\text { (most-likely) }\end{array}$ & -286 & -311 & -180 & -196 & -286 & -311 & -180 & -196 & -286 & -311 & -180 & -196 \\
\hline & $\begin{array}{c}\text { Energy } \\
\text { savings-benefit } \\
\text { (most-likely) }\end{array}$ & - & - & - & - & -185 & -185 & -118 & -118 & -371 & -371 & -236 & -236 \\
\hline & $\begin{array}{c}\mathrm{LCC} / \mathrm{m}^{2} \\
\text { (most-likely } \\
\text { scenario) }\end{array}$ & 261 & 158 & 366 & 273 & 75 & -27 & 248 & 155 & -110 & -212 & 130 & 37 \\
\hline & $\begin{array}{l}\mathrm{LCC} / \mathrm{m}^{2} \\
\text { (minimum } \\
\text { scenario) }\end{array}$ & 335 & 239 & 421 & 334 & 199 & 103 & 340 & 253 & 63 & -33 & 259 & 172 \\
\hline & $\begin{array}{c}\mathrm{LCC} / \mathrm{m}^{2} \\
\text { (maximum } \\
\text { scenario) }\end{array}$ & 207 & 100 & 307 & 209 & -13 & -120 & 150 & 52 & -233 & -340 & -6 & -104 \\
\hline
\end{tabular}


Table A5. Cont.

\begin{tabular}{|c|c|c|c|c|c|c|c|c|c|c|c|c|c|}
\hline \multicolumn{14}{|c|}{$\begin{array}{c}\text { BIPV as Cladding System on New Building (PV Total: } 640 \mathrm{~m}^{2}=470 \mathrm{~m}^{2}(\mathrm{North})+170 \mathrm{~m}^{2}(\text { East)), } 4.0 \% \text { Discount Rate (System Lifetime: } \\
30 \text { Years, Annual Degradation Rate: } 0.7 \% \text {, Inflation Rate: } 2 \%)\end{array}$} \\
\hline \multirow{3}{*}{$\begin{array}{c}\text { Financial } \\
\text { metrics } \\
\text { (most-likely } \\
\text { scenario) }\end{array}$} & $\begin{array}{l}\text { NPV } \\
\text { (SGD) }\end{array}$ & \multicolumn{2}{|c|}{$-166,749-101,423$} & \multicolumn{2}{|c|}{$-234,334-174,957$} & \multirow{2}{*}{$\frac{-48,119}{\mathrm{n} / \mathrm{a}}$} & \multirow{2}{*}{$\begin{array}{c}17,206 \\
19\end{array}$} & \multicolumn{2}{|c|}{$-158,806-99,428$} & \multirow{2}{*}{$\begin{array}{c}70,511 \\
15\end{array}$} & \multirow{2}{*}{$\begin{array}{c}135,836 \\
6\end{array}$} & \multicolumn{2}{|c|}{$-83,278-23,900$} \\
\hline & $\begin{array}{c}\text { DPB } \\
\text { (years) }\end{array}$ & $\mathrm{n} / \mathrm{a}$ & $\mathrm{n} / \mathrm{a}$ & $\mathrm{n} / \mathrm{a}$ & $\mathrm{n} / \mathrm{a}$ & & & $\mathrm{n} / \mathrm{a}$ & $\mathrm{n} / \mathrm{a}$ & & & $\mathrm{n} / \mathrm{a}$ & $\mathrm{n} / \mathrm{a}$ \\
\hline & $\begin{array}{l}\text { IRR } \\
(\%)\end{array}$ & $\mathrm{n} / \mathrm{a}$ & $\mathrm{n} / \mathrm{a}$ & $\mathrm{n} / \mathrm{a}$ & $\mathrm{n} / \mathrm{a}$ & $\mathrm{n} / \mathrm{a}$ & $6.4 \%$ & $\mathrm{n} / \mathrm{a}$ & $\mathrm{n} / \mathrm{a}$ & $8.7 \%$ & $18.2 \%$ & $\mathrm{n} / \mathrm{a}$ & $1.5 \%$ \\
\hline \multirow{3}{*}{$\begin{array}{l}\text { Financial } \\
\text { metrics } \\
\text { (minimum } \\
\text { scenario) }\end{array}$} & \multicolumn{3}{|c|}{ NPV(SGD)-214,305-153,165 } & \multicolumn{2}{|c|}{$-269,741-213,479$} & \multicolumn{2}{|c|}{$-127,298-66,158$} & \multicolumn{2}{|c|}{$-217,920-161,658$} & $-40,292$ & 20,848 & \multicolumn{2}{|c|}{$-166,099-109,837$} \\
\hline & $\begin{array}{c}\text { DPB } \\
\text { (years) }\end{array}$ & $\mathrm{n} / \mathrm{a}$ & $\mathrm{n} / \mathrm{a}$ & $\mathrm{n} / \mathrm{a}$ & $\mathrm{n} / \mathrm{a}$ & $\mathrm{n} / \mathrm{a}$ & 10 & $\mathrm{n} / \mathrm{a}$ & $\mathrm{n} / \mathrm{a}$ & $\mathrm{n} / \mathrm{a}$ & 10 & $\mathrm{n} / \mathrm{a}$ & $\mathrm{n} / \mathrm{a}$ \\
\hline & $\begin{array}{l}\text { IRR } \\
(\%)\end{array}$ & $\mathrm{n} / \mathrm{a}$ & $\mathrm{n} / \mathrm{a}$ & $\mathrm{n} / \mathrm{a}$ & $\mathrm{n} / \mathrm{a}$ & $\mathrm{n} / \mathrm{a}$ & $9.8 \%$ & $\mathrm{n} / \mathrm{a}$ & $\mathrm{n} / \mathrm{a}$ & $\mathrm{n} / \mathrm{a}$ & $8.6 \%$ & $\mathrm{n} / \mathrm{a}$ & $\mathrm{n} / \mathrm{a}$ \\
\hline \multirow{3}{*}{$\begin{array}{l}\text { Financial } \\
\text { metrics } \\
\text { (maximum } \\
\text { scenario): }\end{array}$} & $\begin{array}{l}\mathrm{NPV} \\
\text { (SGD) }\end{array}$ & -132 & $-64,273$ & -196 & $-133,532$ & 8216 & 76,546 & $-96,100$ & $-33,372$ & 149,035 & 217,365 & 4059 & 66,787 \\
\hline & $\begin{array}{c}\text { DPB } \\
\text { (years) }\end{array}$ & $\mathrm{n} / \mathrm{a}$ & $\mathrm{n} / \mathrm{a}$ & $\mathrm{n} / \mathrm{a}$ & $\mathrm{n} / \mathrm{a}$ & 25 & 10 & $\mathrm{n} / \mathrm{a}$ & $\mathrm{n} / \mathrm{a}$ & 10 & 5 & 28 & 13 \\
\hline & $\begin{array}{l}\text { IRR } \\
(\%)\end{array}$ & $\mathrm{n} / \mathrm{a}$ & $\mathrm{n} / \mathrm{a}$ & $\mathrm{n} / \mathrm{a}$ & $\mathrm{n} / \mathrm{a}$ & $4.6 \%$ & $12.3 \%$ & $\mathrm{n} / \mathrm{a}$ & $\mathrm{n} / \mathrm{a}$ & $12.6 \%$ & $23.5 \%$ & $4.3 \%$ & $9.6 \%$ \\
\hline \multicolumn{2}{|c|}{$\begin{array}{l}\mathrm{CO}_{2} \text { savings over the } \\
\text { lifetime (tonnes) }\end{array}$} & 621 & 675 & 621 & 675 & 1112 & 1,167 & 1112 & 1167 & 1604 & 1658 & 1604 & 1658 \\
\hline
\end{tabular}

Table A6. Life-Cycle Cost (LCC) results for BIPV façade as cladding system on a hypothetical new building with an east-west design (IRR-Internal Rate of Return, DPB-Discounted Payback, NPV-Net Present Value).

\section{BIPV as Cladding System on New Building (PV Total: $340 \mathrm{~m}^{2}=170 \mathrm{~m}^{2}$ (West) $+170 \mathrm{~m}^{2}$ (East)), 4.0\% Discount Rate, (System Lifetime: 30 Years, Annual Degradation Rate: $0.7 \%$, Inflation Rate: $2 \%$ )}

\begin{tabular}{|c|c|c|c|c|c|c|c|c|c|c|c|c|}
\hline \multirow{3}{*}{$\begin{array}{c}\text { Energy Saving Scenarios } \\
\text { Electricity Price Customer } \\
\text { Module type }\end{array}$} & \multicolumn{4}{|c|}{ (1) no additional energy savings } & \multicolumn{4}{|c|}{ (2) 1-degree energy savings } & \multicolumn{4}{|c|}{ (3) 2-degrees energy savings } \\
\hline & \multicolumn{2}{|c|}{ Non-contestable } & \multicolumn{2}{|c|}{ Contestable } & \multicolumn{2}{|c|}{ Non-contestable } & \multicolumn{2}{|c|}{ Contestable } & \multicolumn{2}{|c|}{ Non-contestable } & \multicolumn{2}{|c|}{ Contestable } \\
\hline & AGC & Kromatix & AGC & Kromatix & AGC & Kromatix & AGC & Kromatix & AGC & Kromatix & AGC & Kromatix \\
\hline $\begin{array}{l}\text { Blended irradiance } \\
\left(\mathrm{kWh} / \mathrm{m}^{2}\right)\end{array}$ & 817 & 817 & 817 & 817 & 817 & 817 & 817 & 817 & 817 & 817 & 817 & 817 \\
\hline Area factor $\left(\mathrm{Wp} / \mathrm{m}^{2}\right)$ & 156 & 170 & 156 & 170 & 156 & 170 & 156 & 170 & 156 & 170 & 156 & 170 \\
\hline Installed capacity (kWp) & 53 & 58 & 53 & 58 & 53 & 58 & 53 & 58 & 53 & 58 & 53 & 58 \\
\hline Cost per area (SGD/m2) & 548 & 469 & 548 & 469 & 548 & 469 & 548 & 469 & 548 & 469 & 548 & 469 \\
\hline $\begin{array}{l}\text { System installation cost } \\
\text { (SGD) }\end{array}$ & 186,203 & 159,309 & 186,203 & 159,309 & 186,203 & 159,309 & 186,203 & 159,309 & 186,203 & 159,309 & 186,203 & 159,309 \\
\hline Annual O\&M (SGD) & 5100 & 5100 & 5100 & 5100 & 5100 & 5100 & 5100 & 5100 & 5100 & 5100 & 5100 & 5100 \\
\hline Annual O\&M $\left(\mathrm{SGD} / \mathrm{m}^{2}\right)$ & 15 & 15 & 15 & 15 & 15 & 15 & 15 & 15 & 15 & 15 & 15 & 15 \\
\hline $\begin{array}{l}\text { Inverter Replacement } \\
\text { Reserve (SGD) }\end{array}$ & 514 & 573 & 514 & 573 & 514 & 573 & 514 & 573 & 514 & 573 & 514 & 573 \\
\hline Performance ratio (\%) & $80 \%$ & $80 \%$ & $80 \%$ & $80 \%$ & $80 \%$ & $80 \%$ & $80 \%$ & $80 \%$ & $80 \%$ & $80 \%$ & $80 \%$ & $80 \%$ \\
\hline Specific yield $(\mathrm{kWh} / \mathrm{kWp})$ & 654 & 654 & 654 & 654 & 654 & 654 & 654 & 654 & 654 & 654 & 654 & 654 \\
\hline 1st year generation $(\mathrm{kWh})$ & 34,738 & 37,795 & 34,738 & 37,795 & 34,738 & 37,795 & 34,738 & 37,795 & 34,738 & 37,795 & 34,738 & 37,795 \\
\hline $\begin{array}{l}\text { Electricity Grid Emission } \\
\text { Factor }(\mathrm{CO} 2 \mathrm{~g} / \mathrm{kWh})\end{array}$ & 392 & 392 & 392 & 392 & 392 & 392 & 392 & 392 & 392 & 392 & 392 & 392 \\
\hline $\begin{array}{l}\text { Replaced material } \\
\left(\mathrm{SGD} / \mathrm{m}^{2}\right)\end{array}$ & -350 & -350 & -350 & -350 & -350 & -350 & -350 & -350 & -350 & -350 & -350 & -350 \\
\hline $\begin{array}{l}\text { Savings of replaced } \\
\text { material (SGD) }\end{array}$ & $-119,00$ & $0-119,000$ & $-119,00$ & $0-119,000$ & $-119,0$ & $0-119,000$ & $-119,00$ & $0-119,000$ & $-119,0$ & $0-119,000$ & $-119,00$ & $0-119,000$ \\
\hline
\end{tabular}


Table A6. Cont.

BIPV as Cladding System on New Building (PV Total: $340 \mathrm{~m}^{2}=170 \mathrm{~m}^{2}$ (West) $+170 \mathrm{~m}^{2}$ (East)), 4.0\% Discount Rate, (System Lifetime: 30 Years, Annual Degradation Rate: 0.7\%, Inflation Rate: $2 \%$ )

\begin{tabular}{|c|c|c|c|c|c|c|c|c|c|c|c|c|c|c|}
\hline & Net & stment & 198 & 119 & 198 & 119 & 198 & 119 & 198 & 119 & 198 & 119 & 198 & 119 \\
\hline & $\begin{array}{r}\text { Ope } \\
\text { ma }\end{array}$ & $\begin{array}{l}\text { ng and } \\
\text { nance }\end{array}$ & 329 & 329 & 329 & 329 & 329 & 329 & 329 & 329 & 329 & 329 & 329 & 329 \\
\hline & $\begin{array}{r}\mathrm{I} \\
\operatorname{Rep}\end{array}$ & $\begin{array}{l}\text { rter } \\
\text { ement }\end{array}$ & 19 & 22 & 19 & 22 & 19 & 22 & 19 & 22 & 19 & 22 & 19 & 22 \\
\hline LCC & $\begin{array}{r}\text { El } \\
\text { pro } \\
\text { (mo }\end{array}$ & $\begin{array}{l}\text { icity } \\
\text { ction- } \\
\text { efit } \\
\text { ikely) }\end{array}$ & -318 & -346 & -201 & -218 & -318 & -346 & -201 & -218 & -318 & -346 & -201 & -218 \\
\hline $\begin{array}{c}\text { result } \\
(\mathrm{SGD} / \\
\left.\mathrm{m}^{2}\right)\end{array}$ & $\begin{array}{r}1 \\
\text { savir } \\
\text { (mo }\end{array}$ & $\begin{array}{l}\text { rgy } \\
\text { benefit } \\
\text { likely) }\end{array}$ & - & - & - & - & -349 & -349 & -222 & -222 & -698 & -698 & -444 & -444 \\
\hline & $\begin{array}{r}\mathrm{L} \\
(\mathrm{m} \\
\mathrm{Sc}\end{array}$ & $\begin{array}{l}/ \mathrm{m}^{2} \\
\text { likely } \\
\text { rio) }\end{array}$ & 228 & 123 & 346 & 251 & -121 & -225 & 124 & 29 & -469 & -574 & -98 & -193 \\
\hline & & $\begin{array}{l}\mathrm{m}^{2} \\
\text { num } \\
\text { ario) }\end{array}$ & 311 & 213 & 407 & 318 & 55 & -43 & 255 & 166 & -201 & -298 & 103 & 13 \\
\hline & & $\mathrm{m}_{\mathrm{mum}}^{\mathrm{m}^{2}}$ & 169 & 59 & 280 & 179 & -245 & -355 & -15 & -115 & -659 & -769 & -310 & -410 \\
\hline & & $\begin{array}{l}\text { NPV } \\
\text { (SGD) }\end{array}$ & $-77,632$ & $-41,971$ & $-117,57$ & $2-85,425$ & 40,997 & 76,659 & $-42,043$ & -9897 & 159,627 & 195,288 & 33,485 & 65,632 \\
\hline $\begin{array}{r}\mathrm{m \epsilon} \\
(\mathrm{mos}\end{array}$ & ics & $\begin{array}{c}\text { DPB } \\
\text { (years) }\end{array}$ & $\mathrm{n} / \mathrm{a}$ & $\mathrm{n} / \mathrm{a}$ & $\mathrm{n} / \mathrm{a}$ & $\mathrm{n} / \mathrm{a}$ & 14 & 6 & $\mathrm{n} / \mathrm{a}$ & $\mathrm{n} / \mathrm{a}$ & 6 & 3 & 19 & 11 \\
\hline & & $\begin{array}{l}\text { IRR } \\
(\%)\end{array}$ & $\mathrm{n} / \mathrm{a}$ & $\mathrm{n} / \mathrm{a}$ & $\mathrm{n} / \mathrm{a}$ & $\mathrm{n} / \mathrm{a}$ & $9.1 \%$ & $19.1 \%$ & $\mathrm{n} / \mathrm{a}$ & $2.1 \%$ & $20.7 \%$ & $38.4 \%$ & $7.2 \%$ & $13.0 \%$ \\
\hline & & $\begin{array}{l}\text { NPV } \\
\text { (SGD) }\end{array}$ & $-105,73$ & $-72,547$ & $-138,49$ & $5-108,190$ & $-18,729$ & 14,459 & $-86,674$ & $-56,368$ & 68,278 & 101,466 & $-34,853$ & -4547 \\
\hline $\begin{array}{r}\mathrm{me} \\
(\mathrm{min}\end{array}$ & ics & $\begin{array}{c}\text { DPB } \\
\text { (years) }\end{array}$ & $\mathrm{n} / \mathrm{a}$ & $\mathrm{n} / \mathrm{a}$ & $\mathrm{n} / \mathrm{a}$ & $\mathrm{n} / \mathrm{a}$ & $\mathrm{n} / \mathrm{a}$ & 9 & $\mathrm{n} / \mathrm{a}$ & $\mathrm{n} / \mathrm{a}$ & 7 & 3 & $\mathrm{n} / \mathrm{a}$ & $\mathrm{n} / \mathrm{a}$ \\
\hline scel & & $\begin{array}{l}\text { IRR } \\
(\%)\end{array}$ & $\mathrm{n} / \mathrm{a}$ & $\mathrm{n} / \mathrm{a}$ & $\mathrm{n} / \mathrm{a}$ & $\mathrm{n} / \mathrm{a}$ & $\mathrm{n} / \mathrm{a}$ & $9.8 \%$ & $\mathrm{n} / \mathrm{a}$ & $\mathrm{n} / \mathrm{a}$ & $14.5 \%$ & $31.1 \%$ & $\mathrm{n} / \mathrm{a}$ & $2.7 \%$ \\
\hline & & $\begin{array}{l}\text { NPV } \\
\text { (SGD) }\end{array}$ & $-57,455$ & $-20,018$ & $-95,072$ & $-60,945$ & 83,365 & 120,802 & 5088 & 39,214 & 224,184 & 261,621 & 105,247 & 139,374 \\
\hline $\begin{array}{r}\mathrm{me} \\
(\mathrm{max}\end{array}$ & num & $\begin{array}{c}\mathrm{DPB} \\
\text { (years) }\end{array}$ & $\mathrm{n} / \mathrm{a}$ & $\mathrm{n} / \mathrm{a}$ & $\mathrm{n} / \mathrm{a}$ & $\mathrm{n} / \mathrm{a}$ & 10 & 5 & 26 & 13 & 5 & 3 & 11 & 7 \\
\hline sce 1 & & $\begin{array}{l}\text { IRR } \\
(\%)\end{array}$ & $\mathrm{n} / \mathrm{a}$ & $\mathrm{n} / \mathrm{a}$ & $\mathrm{n} / \mathrm{a}$ & $\mathrm{n} / \mathrm{a}$ & $13.1 \%$ & $24.4 \%$ & $4.6 \%$ & $10.2 \%$ & $25.0 \%$ & $44.1 \%$ & $13.0 \%$ & $21.0 \%$ \\
\hline $\begin{array}{r}\mathrm{CO}_{2} \\
\quad \text { lif }\end{array}$ & $\begin{array}{l}\text { vings } \\
\text { me ( } t\end{array}$ & $\begin{array}{l}\text { r the } \\
\text { es) }\end{array}$ & 367 & 399 & 367 & 399 & 858 & 891 & 858 & 891 & 1350 & 1382 & 1350 & 1382 \\
\hline
\end{tabular}

Table A7. Life-Cycle Cost (LCC) results for PV canopy on an existing or a new building (IRR-Internal Rate of Return, DPB-Discounted Payback, NPV-Net Present Value).

\begin{tabular}{|c|c|c|c|c|c|c|}
\hline \multicolumn{7}{|c|}{380 Wp PERC Double-Glass for Roof Canopy (PV Modules Horizontally Installed), 5.19\% Discount Rate } \\
\hline Energy Saving Scenarios & \multicolumn{6}{|c|}{ None } \\
\hline Buildings/area to be covered & \multicolumn{2}{|c|}{1 building, $\sim 400 \mathrm{~m}^{2}$} & \multicolumn{2}{|c|}{5 buildings, $\sim 2000 \mathrm{~m}^{2}$} & \multicolumn{2}{|c|}{10 buildings, $\sim 4000 \mathrm{~m}^{2}$} \\
\hline Electricity Price Customer & $\begin{array}{c}\text { Non- } \\
\text { contestable }\end{array}$ & Contestable & $\begin{array}{c}\text { Non- } \\
\text { contestable }\end{array}$ & Contestable & $\begin{array}{c}\text { Non- } \\
\text { contestable }\end{array}$ & Contestable \\
\hline Module type & \multicolumn{6}{|c|}{ PERC double-glass } \\
\hline \multicolumn{7}{|l|}{ Underlying assumptions: } \\
\hline Total area $\left(\mathrm{m}^{2}\right)$ & 400 & 400 & 2000 & 2000 & 4000 & 4000 \\
\hline
\end{tabular}


Table A7. Cont.

\begin{tabular}{|c|c|c|c|c|c|c|c|c|}
\hline \multicolumn{9}{|c|}{380 Wp PERC Double-Glass for Roof Canopy (PV Modules Horizontally Installed), 5.19\% Discount Rate } \\
\hline \multicolumn{3}{|c|}{ Blended irradiance $\left(\mathrm{kWh} / \mathrm{m}^{2}\right)$} & 1607 & 1607 & 1607 & 1607 & 1607 & 1607 \\
\hline \multicolumn{3}{|c|}{ Area factor $\left(\mathrm{Wp} / \mathrm{m}^{2}\right)$} & 195 & 195 & 195 & 195 & 195 & 195 \\
\hline \multicolumn{3}{|c|}{ Installed capacity $(\mathrm{kWp})$} & 78 & 78 & 389 & 389 & 779 & 779 \\
\hline \multicolumn{3}{|c|}{ Cost per area (SGD/m2) } & 225 & 225 & 195 & 195 & 180 & 180 \\
\hline \multicolumn{3}{|c|}{ System installation cost (SGD) } & 90,000 & 90,000 & 390,000 & 390,000 & 720,000 & 720,000 \\
\hline \multicolumn{3}{|c|}{ Annual O\&M (SGD) } & 4000 & 4000 & 6000 & 6000 & 12,000 & 12,000 \\
\hline \multicolumn{3}{|c|}{ Annual O\&M (SGD/m²) } & 10 & 10 & 3 & 3 & 3 & 3 \\
\hline \multicolumn{3}{|c|}{ Inverter Replacement Reserve (SGD) } & 436 & 436 & 2180 & 2180 & 4360 & 4360 \\
\hline \multicolumn{3}{|c|}{ Performance ratio $(\%)$} & $80 \%$ & $80 \%$ & $80 \%$ & $80 \%$ & $80 \%$ & $80 \%$ \\
\hline \multicolumn{3}{|c|}{ Specific yield $(\mathrm{kWh} / \mathrm{kWp})$} & 1286 & 1286 & 1286 & 1286 & 1286 & 1286 \\
\hline \multicolumn{3}{|c|}{ 1st year generation $(\mathrm{kWh})$} & 100,095 & 100,095 & 500,475 & 500,475 & $1,000,951$ & $1,000,951$ \\
\hline \multicolumn{3}{|c|}{ Annual degradation rate (\%) } & $0.7 \%$ & $0.7 \%$ & $0.7 \%$ & $0.7 \%$ & $0.7 \%$ & $0.7 \%$ \\
\hline \multicolumn{3}{|c|}{ Inflation rate $(\%)$} & $2.0 \%$ & $2.0 \%$ & $2.0 \%$ & $2.0 \%$ & $2.0 \%$ & $2.0 \%$ \\
\hline \multicolumn{3}{|c|}{ System lifetime (years) } & 30 & 30 & 30 & 30 & 30 & 30 \\
\hline \multicolumn{3}{|c|}{ Electricity Grid Emission Factor (CO2g/kWh) } & 392 & 392 & 392 & 392 & 392 & 392 \\
\hline \multicolumn{3}{|c|}{ Replaced material $\left(\mathrm{SGD} / \mathrm{m}^{2}\right)$} & - & - & - & - & - & - \\
\hline \multicolumn{3}{|c|}{ Savings of replaced material (SGD) } & - & - & - & - & - & - \\
\hline \multicolumn{3}{|c|}{ Net Investment } & 225 & 225 & 195 & 195 & 180 & 180 \\
\hline \multirow{7}{*}{$\begin{array}{l}\text { LCC result } \\
\left(\mathrm{SGD} / \mathrm{m}^{2}\right)\end{array}$} & \multicolumn{2}{|c|}{ Operating and maintenance } & 189 & 189 & 57 & 57 & 57 & 57 \\
\hline & \multicolumn{2}{|c|}{ Inverter Replacement } & 12 & 12 & 12 & 12 & 12 & 12 \\
\hline & \multicolumn{2}{|c|}{$\begin{array}{l}\text { Electricity production-benefit } \\
\text { (most-likely) }\end{array}$} & -681 & -423 & -681 & -423 & -681 & -423 \\
\hline & \multicolumn{2}{|c|}{$\begin{array}{c}\text { Energy } \\
\text { savings-benefit(most-likely) }\end{array}$} & - & - & - & - & - & - \\
\hline & \multicolumn{2}{|c|}{$\begin{array}{c}\mathrm{LCC} / \mathrm{m}^{2} \text { (most-likely } \\
\text { scenario) }\end{array}$} & -255 & 2 & -417 & -160 & -432 & -175 \\
\hline & \multicolumn{2}{|c|}{$\mathrm{LCC} / \mathrm{m}^{2}$ (minimum scenario) } & -85 & 128 & -247 & -35 & -262 & -50 \\
\hline & \multicolumn{2}{|c|}{$\mathrm{LCC} / \mathrm{m}^{2}$ (maximum scenario) } & -381 & -139 & -543 & -301 & -558 & -316 \\
\hline & & NPV (SGD) & 101,967 & -947 & 834,536 & 319,964 & $1,729,072$ & 699,927 \\
\hline $\begin{array}{r}\text { Financial met } \\
\text { sce }\end{array}$ & $\begin{array}{l}\text { cs (most-likely } \\
\text { ario) }\end{array}$ & DPB (years) & 9 & $\mathrm{n} / \mathrm{a}$ & 6 & 14 & 5 & 12 \\
\hline & & IRR (\%) & $14.8 \%$ & $\mathrm{n} / \mathrm{a}$ & $21.9 \%$ & $10.9 \%$ & $23.9 \%$ & $11.8 \%$ \\
\hline & & NPV (SGD) & 33,854 & $-51,139$ & 493,969 & 69,004 & $1,047,939$ & 198,009 \\
\hline $\begin{array}{r}\text { Financial me } \\
\text { sce }\end{array}$ & $\begin{array}{l}\text { ics (minimum } \\
\text { ario) }\end{array}$ & DPB (years) & 13 & $\mathrm{n} / \mathrm{a}$ & 7 & 22 & 6 & 19 \\
\hline & & IRR (\%) & $9.5 \%$ & $\mathrm{n} / \mathrm{a}$ & $17.5 \%$ & $6.8 \%$ & $19.4 \%$ & $7.7 \%$ \\
\hline & & NPV (SGD) & 152,402 & 55,656 & $1,086,709$ & 602,982 & $2,233,418$ & $1,265,964$ \\
\hline $\begin{array}{r}\text { Financial me } \\
\text { sce }\end{array}$ & $\begin{array}{l}\text { ics (maximum } \\
\text { ario) }\end{array}$ & DPB(years) & 7 & 14 & 5 & 9 & 4 & 9 \\
\hline & & IRR (\%) & $18.3 \%$ & $9.7 \%$ & $25.3 \%$ & $15.2 \%$ & $27.5 \%$ & $16.4 \%$ \\
\hline $\mathrm{CO}_{2}$ savi & s over the lifeti & he (tonnes) & 1057 & 1057 & 5286 & 5286 & 10,571 & 10,571 \\
\hline
\end{tabular}

\section{References}

1. Energy Market Authority (EMA). Singapore Energy Statistics 2019. Available online: https://www.ema.gov.sg/SingaporeEnergy-Statistics-2019 (accessed on 10 March 2020).

2. Energy Market Authority (EMA). Singapore's Energy Story. Available online: https:/ /www.ema.gov.sg/ourenergystory (accessed on 12 August 2020). 
3. Kosorić, V.; Lau, S.K.; Nobre, A.M.; Tablada, A.; Lau, S.S.Y. A comparison between photovoltaic integration onto roofs and façades of existing public high-rise residential buildings in Singapore. In Proceedings of the 13th Conference on Advanced Building Skin 2018, Bern, Switzerland, 1-2 October 2018; pp. 674-683.

4. Sembcorp Appointment by PUB to Build Singapore's Largest Floating Solar Farm on Tengeh Reservoir. Available online: https: / / www.sembcorp.com/en/media/media-releases/energy /2020/february/sembcorp-appointment-by-pub-to-buildsingapore-s-largest-floating-solar-farm-on-tengeh-reservoir/ (accessed on 15 June 2020).

5. The Straits Times. Sembcorp to Build Singapore's Largest Floating Solar Farm Covering 45 Football Fields. Available online: https:/ / www.straitstimes.com/singapore/environment/sembcorp-to-build-singapores-largest-floating-solar-farm-covering45-football (accessed on 15 June 2020).

6. Kosorić, V.; Lau, S.K.; Tablada, A.; Lau, S.S.Y. General model of photovoltaic (PV) integration into existing public high-rise residential buildings in Singapore-Challenges and benefits. Renew. Sustain. Energy Rev. 2018, 91, 70-89. [CrossRef]

7. Tablada, A.; Kosorić, V.; Huajing, H.; Chaplin, I.K.; Lau, S.K.; Yuan, C.; Lau, S.S.Y. Design optimisation of productive façades: Integrating photovoltaic and farming systems at the Tropical Technologies Laboratory. Sustainability, 2018; 10, 3762. [CrossRef]

8. Lu, Y.; Chang, R.; Shabunko, V.; Yee, A.T.L. The implementation of building-integrated photovoltaics in Singapore: Drivers versus barriers. Energy 2019, 168, 400-408. [CrossRef]

9. Energy Market Authority (EMA). Available online: https://www.ema.gov.sg/Solar_Photovoltaic_Systems.aspx (accessed on 25 June 2020).

10. Solarmagazine. Singapore Advances towards Solar, Clean Energy Goals But Could More Be Done? Available online: https: / / solarmagazine.com/solar-profiles/singapore/ (accessed on 20 June 2020).

11. Ballif, C.; Perret-Aebi, L.-E.; Lufkin, S.; Rey, E. Integrated thinking for photovoltaics in buildings. Nat. Energy 2018, 3, 438-442. [CrossRef]

12. Attoye, D.E.; Aoul, K.A.T.; Hassan, A. A review on building integrated photovoltaic façade customization potentials. Sustainability 2017, 9, 2287. [CrossRef]

13. Asian Power. Singapore to Deploy 2GW of Solar Power by 2030. Available online: https://asian-power.com/power-utility / news/singapore-deploy-2gw-solar-power-2030 (accessed on 15 September 2020).

14. UPDATE of the Solar Photovoltaic (PV) Roadmap for Singapore. Available online: http://www.seris.sg/doc/publications/ Update-of-the-Solar-Roadmap-for-Singapore-(March-2020).pdf (accessed on 15 September 2020).

15. Heinstein, P.; Ballif, C.; Perret-Aebi., L.-E. Building Integrated Photovoltaics (BIPV): Review, Potentials, Barriers and Myths. Green 2013, 3, 125-156. [CrossRef]

16. Prieto, A.; Knaack, U.; Auer, T.; Klein, T. Solar façades-Main barriers for widespread façade integration of solar technologies. J. Façade Des. Eng. 2017, 5, 51-62. [CrossRef]

17. Goh, K.C.; Goh, H.H.; Yap, A.B.K.; Masrom, M.A.N.; Mohamed, S. Barriers and drivers of Malaysian BIPV application: Perspective of developers. Procedia Eng. 2017, 180, 1585-1595. [CrossRef]

18. Karakaya, E.; Sriwannawit, P. Barriers to the adoption of photovoltaic systems: The state of the art. Renew. Sustain. Energy Rev. 2015, 49, 60-66. [CrossRef]

19. Yang, R.J. Overcoming technical barriers and risks in the application of building integrated photovoltaics (BIPV): Hardware and software strategies. Autom. Constr. 2015, 51, 92-102. [CrossRef]

20. Yang, R.J.; Zou, P.X. Building integrated photovoltaics (BIPV): Costs, benefits, risks, barriers and improvement strategy. Int. J. Constr. Manag. 2016, 16, 39-53. [CrossRef]

21. Azadian, F.; Radzi, M.A.M. A general approach toward building integrated photovoltaic systems and its implementation barriers: A review. Renew. Sustain. Energy Rev. 2013, 22, 527-538. [CrossRef]

22. Wolske, K.; Stern, P.C.; Dietz, T. Explaining Interest in Adopting Residential Solar Photovoltaic Systems in the United States: Towards an Integration of Behavioral Theories. Energy Res. Soc. Sci. 2017, 25, 134-151. [CrossRef]

23. Koinegg, J.; Brudermann, T.; Posch, A.; Mrotzek, M. "It Would Be a Shame if We Did Not Take Advantage of the Spirit of the Times". An Analysis of Prospects and Barriers of Building Integrated Photovoltaics. Gaia Ecol. Perspect. Sci. Soc. 2013, 22, 39-45. [CrossRef]

24. Agathokleous, R.A.; Kalogirou, S.S. Status, barriers and perspectives of building integrated photovoltaic systems. Energy 2020, 191, 116471. [CrossRef]

25. Reddy, P.; Gupta, M.V.N.S.; Nundy, S.; Karthick, A.; Ghosh, A. Status of BIPV and BAPV System for Less Energy-Hungry Building in India-A Review. Appl. Sci. 2020, 10, 2337. [CrossRef]

26. Wall, M.; Probst, M.C.C.; Roecker, C.; Dubois, M.C.; Horvat, M.; Jorgensen, O.B.; Kappel, K. Achieving Solar Energy in Architecture-IEA SHC Task 41. Energy Procedia 2012, 30, 1250. [CrossRef]

27. Farkas, K.; Horvat, M. Report T.41.A.1. Building Integration of Solar Thermal and Photovoltaics-Barriers, Needs and Strategies. 2012. Available online: https://task41.iea-shc.org/Data/Sites/1/publications/T41A1_Survey_FinalReport_May2012.pdf (accessed on 12 February 2021).

28. Munari Probst, M.C.; Roecker, C. (Eds.) Solar Energy Systems in Architecture, Integration Criteria and Guidelines. 2012. Available online: https:/ /task41.iea-shc.org/Data/Sites/1/publications/T41DA2-Solar-Energy-Systems-in-Architecture-28March2013.pdf (accessed on 12 February 2021). 
29. Farkas, K. (Ed.) Designing Photovoltaic Systems for Architectural Integration, Criteria and Guidelines for Product and Systems Dvelopers. 2013. Available online: https://task41.iea-shc.org/Data/Sites/1/publications/task41A3-2-Designing-Photovoltaic-Systemsfor-Architectural-Integration.pdf (accessed on 12 February 2021).

30. Hagen, R.; Jørgensen, O.B. The Communication Process, Subtask C: Communication Guideline. Available online: https: //task41.iea-shc.org/Data/Sites/1/publications/T41C1-CommunicationsGuide-2012.pdf (accessed on 12 February 2021).

31. Building and Construction Authority (BCA). Available online: https://www.bca.gov.sg/greenmark/green_mark_buildings.html (accessed on 10 September 2020).

32. Ministry of National Development (MND), BCA Green Mark. Available online: https://www.mnd.gov.sg/our-work/greeningour-home/bca-green-mark (accessed on 10 September 2020).

33. Shelly, C. Residential solar electricity adoption: What motivates, and what matters? A case study of early adopters. Energy Res. Soc. Sci. 2014, 2, 183-191. [CrossRef]

34. Kosorić, V.; Huang, H.; Tablada, A.; Lau, S.-K.; Tan, H.T.W. Survey on the social acceptance of the productive façade concept integrating photovoltaic and farming systems in high-rise public housing blocks in Singapore. Renew. Sustain. Energy Rev. 2019, 111, 197-214. [CrossRef]

35. Attoye, D.E.; Adekunle, T.O.; Tabet Aoul, K.A.; Hassan, A.; Attoye, S.O. A Conceptual Framework for a Building Integrated Photovoltaics (BIPV) Educative-Communication Approach. Sustainability 2018, 10, 3781. [CrossRef]

36. Construction Products Regulation, Regulation (EU) No 305/2011 of the European Parliament and the Council of 9 March 2011. Official Journal of the European Union. Available online: http:/ / eur-lex.europa.eu/legal-content/EN/TXT/PDF/?uri=CELEX: 32011R0305\&from=EN (accessed on 10 September 2020).

37. Swiss BIPV Competence Centre. Available online: ww.bipv.ch (accessed on 5 June 2020).

38. Bieri, M. Methodology Description: SERIS Future Power Price Scenarios. 2018. Available online: https:/ / www.solar-repository. sg/archives (accessed on 28 March 2020).

39. Bhati, A.; Hansen, M.; Chan, C.M. Energy conservation through smart homes in a smart city: A lesson for Singapore households. Energy Policy 2017, 104, 230-239. [CrossRef]

40. Direct Market Consumers. Available online: https://www.emcsg.com/aboutthemarket/marketparticipation/directconsumers (accessed on 12 February 2021).

41. Wong, K.; Meng, T.W.; Kiat, Y.B.; Allen \& Gledhill LLP. Electricity Regulation in Singapore: Overview. Available online: https:/ / uk.practicallaw.thomsonreuters.com/7-637-5107 (accessed on 12 February 2021).

42. Dominguez, A.; Kleissl, J.; Luvall, J.C. Effects of solar photovoltaic panels on roof heat transfer. Sol. Energy 2011, 85, 2244-2255. [CrossRef]

43. Xu, X.Y.; Ang, B.W. Analysing residential energy consumption using index decomposition analysis. Appl. Energy 2014, 113, 342-351. [CrossRef]

44. Monetary Authority of Singapore. Yield of 30-Year Government Bond. Available online: https:/ / eservices.mas.gov.sg/Statistics/ fdanet/BenchmarkPricesAndYields.aspx (accessed on 24 September 2020).

45. Energy Market Authority. Review of the Long Run Marginal Cost Parameters for Setting the Vesting Contract Price for 2021 and 2022, Consultation Paper, 30 July 2020. Available online: https:/ /www.ema.gov.sg/ConsultationDetails.aspx?con_sid=20200730 uqhaTEHbVaIp (accessed on 24 September 2020).

46. Monetary Authority of Singapore. Interest Rates of Banks and Finance Companies for Housing Loans for 15 Years. Available online: https:/ / secure.mas.gov.sg/msb/InterestRatesOfBanksAndFinanceCompanies.aspx (accessed on 24 September 2020).

47. Monetary Authority of Singapore. SGS Prices and Yields-Benchmark Issues. Available online: https://eservices.mas.gov.sg/ Statistics / fdanet/BenchmarkPricesAndYields.aspx (accessed on 24 September 2020).

48. National Solar Repository of Singapore (NSR), Building Integrated Photovoltaics (BIPV) Life-Cycle Cost (LCC) Calculator. Available online: https:/ / www.solar-repository.sg/lcc-calculator/ (accessed on 24 September 2020).

49. Taleb, H.M.; Pitts, A.C. The potential to exploit use of building-integrated photovoltaics in countries of the Gulf Cooperation Council. Renew. Energy 2009, 34, 1092-1099. [CrossRef]

50. Housing \& Development Board (HDB). Available online: https:/ /www.hdb.gov.sg/ (accessed on 10 September 2020).

51. Chang, R.; Cao, Y.; Lu, Y.; Shabunko, V. Should BIPV technologies be empowered by innovation policy mix to facilitate energy transitions? Revealing stakeholders' different perspectives using Q methodology. Energy Policy 2019, 129, 307-318. [CrossRef]

52. Bieri, M.; Shabunko, V.; Zhao, L.; Quek, E.; Reindl, T. An economic viability study for building-integrated photovoltaic (BIPV) in the tropics. In Proceedings of the 26th International Photovoltaic Science and Engineering Conference (PVSEC-26), Singapore, 24-28 October 2016.

53. Gholami, H.; Røstvik, G.H. Economic analysis of BIPV systems as a building envelope material for building skins in Europe. Energy 2020, 204, 117931. [CrossRef]

54. Khoo, Y.S.; Nobre, A.; Malhotra, R.; Yang, D.; Rüther, R.; Reindl, T.; Aberle, A.G. Optimal orientation and tilt angle for maximizing in-plane solar irradiation for PV applications in Singapore. IEEE J. Photovolt. 2014, 4, 647-653. [CrossRef]

55. Energy Market Authority. Statistics, Installed Capacity of Grid-Connected Solar Photovoltaic (PV) Systems by User Type, 2008-Q2 2020. Available online: https://www.ema.gov.sg/cmsmedia/47RSU.pdf (accessed on 24 September 2020). 